\title{
Changes in stand structure and species diversity following clearcutting in central Appalachian hardwoods
}

\author{
Mark Benjamin Brashears \\ West Virginia University
}

Follow this and additional works at: https://researchrepository.wvu.edu/etd

\section{Recommended Citation}

Brashears, Mark Benjamin, "Changes in stand structure and species diversity following clearcutting in central Appalachian hardwoods" (2001). Graduate Theses, Dissertations, and Problem Reports. 1151. https://researchrepository.wvu.edu/etd/1151

This Thesis is protected by copyright and/or related rights. It has been brought to you by the The Research Repository @ WVU with permission from the rights-holder(s). You are free to use this Thesis in any way that is permitted by the copyright and related rights legislation that applies to your use. For other uses you must obtain permission from the rights-holder(s) directly, unless additional rights are indicated by a Creative Commons license in the record and/ or on the work itself. This Thesis has been accepted for inclusion in WVU Graduate Theses, Dissertations, and Problem Reports collection by an authorized administrator of The Research Repository @ WVU. For more information, please contact researchrepository@mail.wvu.edu. 
Changes in Stand Structure and Species Diversity

\title{
Following Clearcutting in Central Appalachian Hardwoods
}

\author{
Mark Benjamin Brashears
}

Thesis submitted to the

College of Agriculture, Forestry, and Consumer Sciences

at West Virginia University

in partial fulfillment of the requirements

for the degree of

Master of Science

in

Forestry

Mary Ann Fajvan, Ph.D., Chair

Ray R. Hicks, Jr., Ph.D.

Thomas M. Schuler, Ph.D.

\section{Division of Forestry}

Morgantown, West Virginia

2001

Keywords: Silviculture, Clearcut, Stand Development, Species Diversity, Yellow-Poplar 


\title{
ABSTRACT \\ Changes in Stand Structure and Species Diversity Following Clearcutting in Central Appalachian Hardwoods
}

\author{
Mark Benjamin Brashears
}

The clearcutting of second-growth Appalachian hardwood forests may cause a reduction in species diversity of the new cohort. This study measured changes in species composition, diversity, and stand structural characteristics following clearcutting of a second-growth hardwood forest. To evaluate the temporal changes in importance of central Appalachian hardwood tree species, thirteen clearcuts on good-excellent sites in West Virginia were inventoried before harvesting and 2-26 years after harvesting. Shannon-Weaver's diversity index (H'), Pielou's evenness index (E), and species richness $(\mathrm{S})$ were calculated before and after clearcutting. Species diversity and evenness has decreased, and species richness has remained stable following clearcutting. Species such as Liriodendron tulipifera, Betula lenta, and Robinia pseudoacacia increased in importance in the postharvest stands, whereas Quercus rubra, Carya spp., and Fagus grandifolia decreased. The overstory of the future stand will be dominated by Liriodendron tulipifera and Tilia americana, and the understory will be primarily Acer saccharum. 


\section{ACKNOWLEDGEMENTS}

I would like to thank Dr. Thomas M. Schuler of the Fernow Experimental Forest, for his insight and support. I would also like to thank Dr. Ray R. Hicks Jr. of West Virginia University, for his assistance in completing my thesis. I would especially like to thank Dr. Mary Ann Fajvan of West Virginia University, for accepting me into the program and for her knowledge and continuous support throughout my tenure at West Virginia University. I would also like to thank Tony Scardina, my father Mark Brashears, and my fiancée Jennifer Hammer for their dedication and assistance through numerous hot and rainy days of field work. I thank my parents, Mark and Vicki Brashears, and fiancée Jennifer Hammer for their continued love and support throughout all of my endeavors. Thanks to all of you who have made my time at West Virginia University and my research truly enjoyable. 


\section{Table of Contents}

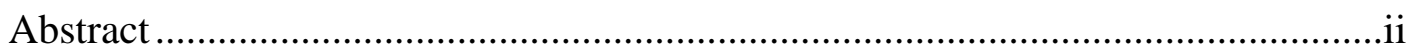

Acknowledgements .....................................................................................ii

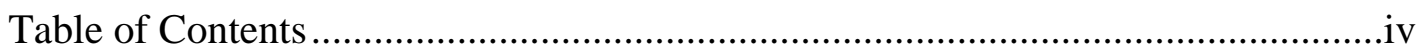

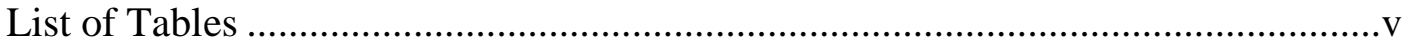

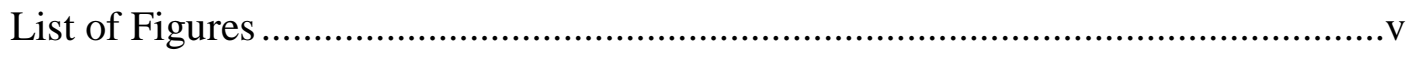

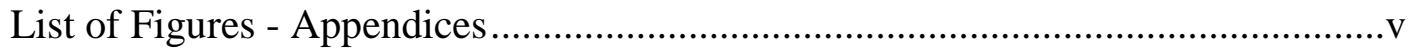

Chapter 1

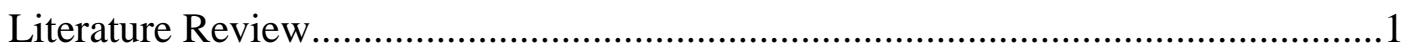

Chapter 2

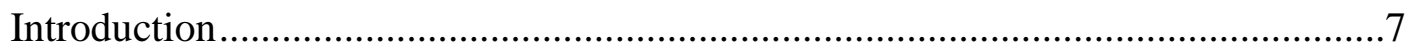

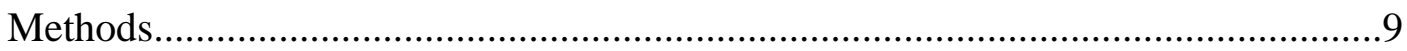

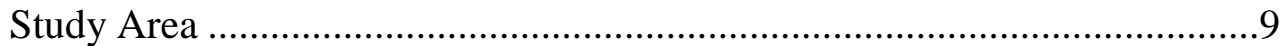

Stand History and Development ................................................................

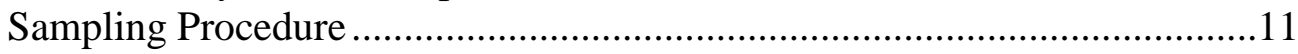

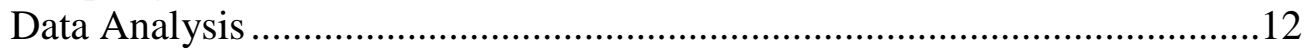

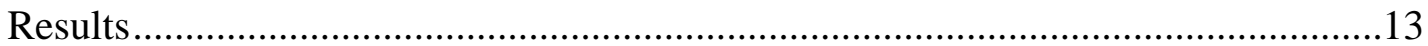

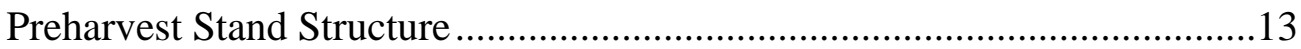

Postharvest Stand Structure .......................................................................14

Species Composition....................................................................14

Species Diversity and Richness .....................................................16

Canopy Structure …………………………………………….....16

Comparison of Preharvest and Postharvest Structures ..................................17

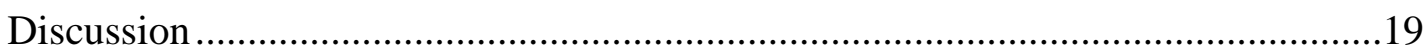

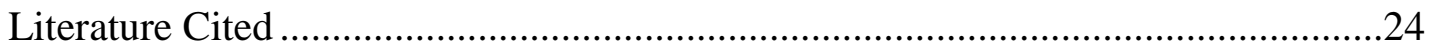

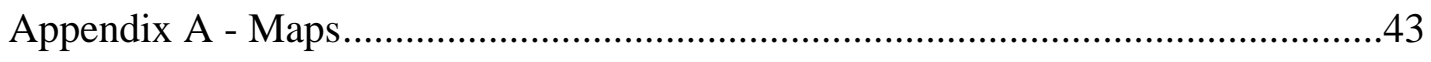




\section{List of Tables}

Table 1. Preharvest Species Composition, Relative Trees per Hectare, Relative Basal Area per Hectare, and Relative Importance Value 28

Table 2. Importance Values for each Age Class, Crown Class, and Canopy Strata

Table 3. Preharvest Relative Density of Advanced Regeneration...........................31

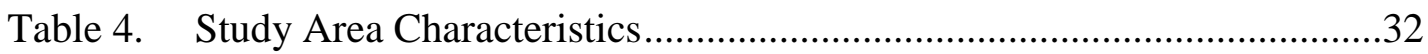

Table 5. Postharvest Species Composition, Relative Trees per Hectare, Relative Basal Area per Hectare, and Relative Importance Value

Table 6. Postharvest Species Importance Value, Relative Trees per Hectare, and Relative Basal Area per Hectare for each Age Class 35

Table 7. Relative Basal Area per Hectare for each Age Class, Crown Class,

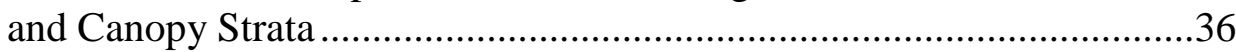

Table 8. Relative Trees per Hectare for each Age Class, Crown Class,

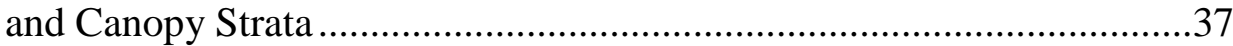

Table 9. Trees with Sprout Origin in Postharvest Stands .......................................38

\section{List of Figures}

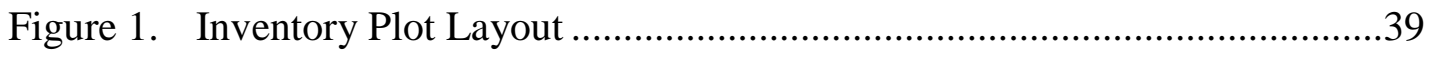

Figure 2. DCA: Pre and Postharvest Importance Value Ordination .........................40

Figure 3. DCA: Postharvest Importance Value Ordination .......................................41

Figure 4. Overstory Composition .....................................................................42

\section{List of Figures - Appendices}

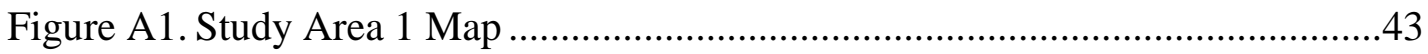

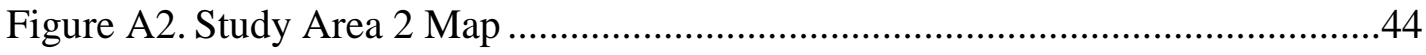

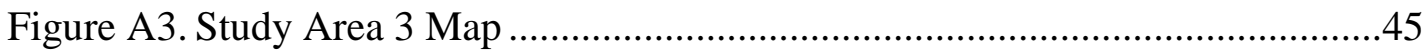




\section{Chapter 1}

\section{Literature Review}

The central Appalachian hardwood forest region consists of maturing, second growth stands. The high species and structural diversity of these forests were influenced by heavy logging, periodic fires, and the death of the American chestnut (Castanea dentata) (Hicks, 1998). Current stands typically contain more than 20 tree species representing a range of silvical characteristics (Miller and Kochenderfer, 1998). Typical shade intolerant species include yellow-poplar (Liriodendron tulipifera), black cherry (Prunus serotina), black locust (Robinia pseudoacacia), and sassafras (Sassafras albidum). Species of intermediate shade tolerance include northern red oak (Quercus rubra), chestnut oak (Quercus prinus), white oak (Quercus alba), hickories (Carya spp.), white ash (Fraxinus americana), red elm (Ulmus rubra), and black birch (Betula lenta). Common shade tolerant species are sugar maple (Acer saccharum), red maple (Acer rubrum), American beech (Fagus grandifolia), and American basswood (Tilia americana) (Miller and Kochenderfer, 1998; Trimble, 1973).

As second-growth forests are harvested, maintenance of species diversity is a constant consideration of forest managers. For example, silvicultural regeneration methods that create canopy openings $>0.2$ hectare can be used to establish new cohorts that reflect the species composition of the forests that preceded them (Dale et al., 1995; Trimble, 1973). Openings smaller than this will regenerate stands with higher densities of shade tolerant species than found before (Dale et al., 1995). However, the presence of shade tolerant advanced regeneration can prolong the achievement of preharvest species dominance in the overstory. For example, abundant red maple advanced regeneration 
resulted in a postharvest stand with higher proportions of this species than in the preharvest composition (Arthur et al., 1997). A similar pattern was found for sugar maple, where $2 / 3$ to $3 / 4$ of stand composition 20 years after clearcutting, was attributed to abundant advanced regeneration present before the harvest (Marquis, 1967; Marks, 1973; Wang and Nyland, 1993). Heavy advanced regeneration of sugar maple also can impede the regeneration of shade intolerant species after clearcutting in West Virginia (Trimble, 1973).

Short-lived early successional species also affect the composition of stands following clearcutting. Species such as fire cherry (Prunus pensylvanica), quaking aspen (Populus tremuloides), and striped maple (Acer pensylvanicum) can dominate the overstory of stands immediately following clearcutting (Marquis, 1967; Wang and Nyland, 1996). These species are short-lived and their mortality releases lower canopy layers of mostly shade tolerant species that eventually dominate these stands (Marquis, 1967; Wang and Nyland, 1996). Fire cherry and striped maple have a typical life span of 35 years (Wang and Nyland, 1993; Wendel, 1990) and quaking aspen has high mortality by age 55-60 (Perala, 1990). Black birch shows a similar early successional pattern. Within 5 years following clearcutting, black birch dominated stands in the southern Appalachians (Beck and Hooper, 1986). By age 10, yellow-poplar and black locust had surpassed black birch. According to Lamson (1990), black birch grows very rapidly following a disturbance, yet usually succumbs to competition by the age of 20 . Hibbs (1983) did not find this pattern in New England. Forty years following a hurricane, black birch comprised $20 \%$ of the co-dominant stems. 
The sprouting ability of some species like American basswood, red maple, and oak allows these species to compete with faster growing species that originate from seed following clearcutting. This ability can give these species an advantage when competing with faster growing species, and enable them to achieve a dominant position in these newly created stands (Arthur et al., 1997). Following clearcutting, vigorous sprouting allowed red maple to increase in importance when compared to preharvest composition (Arthur et al., 1997). Beck and Hooper (1986) also found that sprout-origin stems strengthened the overall importance of red maple following clearcutting. In addition, nearly all free-to-grow stems, except for yellow-poplar and black birch, were of sprout origin.

Appropriately applied clearcutting removes an entire tree community creating sufficient growing space for the initiation of many species (Nyland, 1996). Species diversity peaks during stand initiation (Oliver and Larson, 1996) and species composition is indicative of the previous stand. Comparisons of stand structure before and after clearcutting eastern hardwoods have found that species diversity and richness generally increase soon after harvest and become more similar to preharvest conditions as stand development proceeds (Elliott et. al., 1997; Elliott and Swank, 1994; Hibbs, 1983; Wang and Nyland, 1993).

In southern Appalachian cove hardwoods, species richness increased up to 8 years following clearcutting (Elliott et al., 1997). During this same period, species diversity was generally stable, but decreased between 8 and 17 years. The decrease in diversity was attributed to increased dominance of yellow-poplar and black locust. Elliott and Swank (1994) found that diversity was highest soon after clearcutting, and then declined 
as the stand entered stem exclusion. Hibbs (1983) found this same pattern in central New England; species diversity increased immediately following the disturbance and gradually declined after 10 to 15 years. In northern hardwoods, Wang and Nyland (1993), attributed increased species richness following clearcutting to the addition of aggressive pioneer species like fire cherry, quaking aspen, and black birch.

Third generation stands originating after clearcutting appear to be more homogeneous than the stand that preceded them. During stem exclusion, long-lived species that can sustain rapid height growth will eventually dominate the overstory. On high quality growing sites in West Virginia, yellow-poplar, black locust, black birch, and black cherry have increased in dominance following clearcutting (Trimble and Hart, 1961; Trimble, 1972; Trimble, 1973). Trimble and Hart (1961) documented that stands 10 years following clearcutting on excellent sites, would be dominated by yellow-poplar, black locust, and sugar maple. In another similar study, Trimble (1972) found high amounts of black birch, sugar maple, yellow-poplar, white ash, and black cherry in stems $<2.54 \mathrm{~cm}$ dbh 7 years after clearcutting. The stems $\geq 2.54 \mathrm{~cm}$ dbh were primarily sugar maple, American basswood, ironwood (Ostrya virginiana), black locust, and black cherry. On good sites, black locust was the most abundant species $\geq 2.54 \mathrm{~cm} \mathrm{dbh}$. The excellent sites in this study were revisited at age 12 (Trimble, 1973), and a dramatic increase in the amount of black birch and yellow-poplar had occurred. At this point, black birch, sugar maple, yellow-poplar, black cherry, and ironwood were the five most numerous species. The longest any of these studies were followed was 12 years, and all concluded that yellow-poplar was becoming an increasingly dominant component in these young stands. 
Similar trends have been noted for yellow-poplar, black locust, and black birch in the southern Appalachians (Elliott et. al., 1997; Beck and Hooper, 1986; Parker and Swank, 1982). Seventeen years following clearcutting in North Carolina, yellow-poplar is the most dominant species, contributing $22 \%$ of the total basal area in a cove-hardwood community and $44 \%$ of the total basal area in a mixed-hardwood community (Elliott et al., 1997). The cove-hardwoods also had high densities of black birch, rhododendron (Rhododendron maximum), and black locust. In the mixed-hardwoods, black locust followed yellow-poplar and comprised $21 \%$ of the basal area. Collectively, these two species account for $65 \%$ of the total stand basal area. Yellow-poplar comprises nearly twice the amount of basal area then prior to clearcutting. Dramatic decreases were documented for northern red oak (from 15\% to 6\%) and hickory (from 18\% to 1\%) in the cove-hardwoods and for black oak (Quercus velutina) (from 21\% to <1\%) and hickory (from $17 \%$ to $<1 \%$ ) in the mixed-hardwoods.

Beck and Hooper (1986) found similar results after clearcutting a mixedhardwood stand, also located in western North Carolina. This study found that five years after clearcutting, black birch, black locust, and yellow-poplar were the most abundant free-to-grow stems. Black birch declined rapidly by the age of ten, where it had been surpassed by black locust and yellow-poplar. By the age of fifteen, yellow-poplar became the most dominant species. Twenty years following clearcutting, the new stand was dominated by yellow-poplar, black locust, red maple, and black birch. Yellowpoplar and red maple steadily increased their number of free-to-grow stems, while all the other species decreased. 
In all of these studies, yellow-poplar shows the greatest increase in importance from stand initiation through early stem exclusion. Yellow-poplar is a long-lived species and has the fastest height growth of all Appalachian hardwoods. Early in stand development, yellow-poplar can achieve and maintain a dominant position in the overstory stratum (Beck, 1990).

The objective of this study is to evaluate the temporal changes in relative importance of Appalachian hardwood tree species for a period of 26 years following clearcutting. A chronosequence of 13 clearcuts was used to assess stand development changes. Comparisons of species diversity and richness of preharvest and postharvest stands were used to assess overall changes in species dominance. For each age class in the chronosequence, evaluation of species canopy importance was used to assess early competitive interactions among species. 


\section{Chapter 2}

\section{Introduction}

The central Appalachian hardwood forest region consists of maturing, second growth stands. The high species and structural diversity of these forests was influenced by heavy logging, periodic fires, and the death of the American chestnut (Hicks, 1998). Current stands typically contain more than 20 tree species representing a range of silvical characteristics (Miller and Kochenderfer, 1998). As second generation forests are harvested, maintenance of species diversity is a constant consideration of forest managers. For example, silvicultural regeneration methods that create canopy openings > 0.2 hectare can be used to establish new cohorts that reflect the species composition of the forests that preceded them (Dale et al., 1995; Trimble, 1973). However, the presence of shade tolerant advanced regeneration (Arthur et al., 1997; Wang and Nyland, 1993), and/or dominance of short-lived early successional species (Marks, 1973; Marquis, 1967; Walters and Nyland, 1989; Wang and Nyland, 1996), can prolong the achievement of preharvest species dominance in the overstory.

Appropriately applied clearcutting removes an entire tree community creating sufficient growing space for the initiation of many species (Nyland, 1996). Species diversity peaks during stand initiation and species composition is indicative of the previous stand. During stem exclusion, dominant species that can sustain rapid height growth will eventually dominate the overstory (Oliver and Larson, 1996). Comparisons of stand structure before and after clearcutting eastern hardwoods indicate that species diversity and richness generally increase soon after harvest and become more similar to 
preharvest conditions as stand development proceeds (Elliott et. al., 1997; Elliott and Swank, 1994; Hibbs, 1983; Wang and Nyland, 1993).

Third generation stands originating after clearcutting appear to be more homogeneous than previous stands. Site quality strongly influences which species will dominate a stand (Trimble, 1973). On high quality growing sites in West Virginia, yellow-poplar, black locust, black birch, and black cherry have increased in dominance following clearcutting (Trimble and Hart, 1961; Trimble, 1972; Trimble, 1973). Similar trends have been noted for yellow-poplar, black locust, and black birch in the southern Appalachians (Elliott et. al., 1997; Beck and Hooper, 1986; Parker and Swank, 1982). In all of these studies, yellow-poplar shows the greatest increase in species importance from stand initiation through early stem exclusion. Yellow-poplar is a long-lived species and has the fastest height growth of all Appalachian hardwoods. Early in stand development, yellow-poplar can achieve and maintain a dominant position in the overstory stratum (Beck, 1990).

A chronosequence of 13 clearcuts was used to evaluate the temporal changes in relative importance of Appalachian hardwood tree species over 26 years. Stand-level comparisons of preharvest and postharvest species diversity, evenness, and richness were used to assess overall changes in tree species dominance. In addition, for each age class in the chronosequence, preharvest and postharvest species canopy importance, was assessed to determine the effect of species canopy position on calculations of diversity, evenness, and richness. 


\section{Methods}

\section{Study Areas}

The study areas are located on the Fernow Experimental Forest $\left(39.03^{\circ} \mathrm{N}\right.$, $79.67^{\circ} \mathrm{W}$ ) near Parsons in north-central West Virginia. The 1900-ha Fernow is part of the USDA Forest Service Northeastern Research Station. The land type association is the Allegheny Front Sideslopes (Ba10) (DeMeo et al., 1995) and the ecological land type is the Allegheny Mountain section (M221B) of the Central Appalachian Broadleaf Forest (M221) (McNab and Avers, 1994). The forest vegetation type is classified as the Allegheny Mountain section of the mixed mesophytic forest (Braun, 1950). Average annual precipitation is $143 \mathrm{~cm}$ with a mean of $71 \mathrm{~cm}$ during the growing season (May through October) (Pan et al., 1997). There are an average of 145 frost-free days per year.

The study areas lie within a north-facing cove with elevations ranging from 610 to 914 meters above sea level. The topography is mountainous, with some slopes as steep as $60 \%$. Soils are classified as Dekalb, Calvin, and Belmont series, which are moderately deep to deep, well drained, and medium textured loams (Losche and Beverage, 1967). The highly acidic, Dekalb soils are generally found on the upper slopes. Middle slopes are occupied by the medium acidic Calvin soils. Lower slopes contain Belmont soils, which are slightly acidic to neutral. Small amounts of Meckesville soils also are present. All soil types are of shale and/or sandstone origin. Natural soil fertility is moderate to high with northern red oak site indices ranging from 23 to 24 meters.

\section{Stand History and Development}

Current forest composition on the Fernow Experimental Forest was influenced by human and natural disturbances. Logging from 1903 to 1911 (Trimble, 1977) was heavy, 
but left behind scattered unwanted trees because of poor form, inadequate size, or species type (Schuler, 1998). Species considered undesirable included sugar maple, American beech, birch (Betula spp.), and hickory. The chestnut blight fungus (Cryphonectrim parasitica) caused a $25 \%$ volume reduction in stands on the Fernow during the $1930 \mathrm{~s}$ (Weitzman, 1949). Grazing and fire have been absent from these stands since 1915 (Schuler, 1998).

The age structure of second-growth stands is irregular and may contain up to three cohorts. Species composition is dominated by the Appalachian mixed hardwood forest type (Smith et al., 1983). Important overstory species include yellow-poplar, sugar maple, American basswood, American beech, and northern red oak. Other common overstory species are black cherry, red elm, black locust, white ash, yellow birch (Betula alleghaniensis), red maple, and hickory. Other species present in the study areas include black birch, butternut (Juglans cinerea), black walnut (Juglans nigra), chestnut oak, cucumber magnolia (Magnolia acuminata), flowering dogwood (Cornus florida), fire cherry, ironwood, sassafras, downy serviceberry (Amelanchier arborea), and white oak. Important understory species are sugar maple and American beech.

Our study examined 13 strip clearcuts in 3 study areas. The clearcuts range in size from 0.32 to 2.09 hectares, and the width of each strip is approximately 50 meters. Harvesting began in 1974 in Study Area 1, 1977 in Study Area 2, and 1978 in Study Area 3. Additional clearcuts were made 10 and 20 years following the initial harvest on each of these areas. Thus, each study area contains stands that are 22-26, 12-16, and 2-6 years old. All study areas received a silvicultural clearcut where all stems greater than $2.54 \mathrm{~cm}$ 
were felled with chainsaws and removed with rubber-tired skidders. Non-merchantable stems, cull trees, and tops were left on site.

\section{Sampling Procedures}

Immediately prior to each harvest, all stems $\geq 12.7 \mathrm{~cm}$ diameter at breast height (dbh) were inventoried according to species and dbh. At this same time, 0.0004 ha sample plots were used to inventory stems $<2.54 \mathrm{~cm} \mathrm{dbh}$ and 0.004 ha plots were used to inventory trees $\geq 2.54 \mathrm{~cm}$ dbh and $<12.7 \mathrm{~cm}$ dbh to assess the species composition of the advanced regeneration and understory. During the summer of 2000, stand structure variables were measured in 13 stands using a nested plot design. Plots were systematically located along three transects running parallel to the longest side of each study area. Two transects were each placed $10 \mathrm{~m}$ from the edges of the cut. The third transect was placed in the center of the study area. Plots were established equidistant along a transect, resulting in 1 to 7 plots per transect depending on the size of the clearcut (Figure 1).

Circular 0.0004 ha plots were used to inventory trees $<2.54 \mathrm{~cm} \mathrm{dbh,} 0.004$ ha plots were used to inventory trees $\geq 2.54 \mathrm{~cm} \mathrm{dbh}$ and $<12.7 \mathrm{~cm} \mathrm{dbh}$, and 0.02 ha plots were used to inventory trees $\geq 12.7 \mathrm{~cm} \mathrm{dbh}$. Trees were classified according to species, origin, and 3 height classes $(<0.30 \mathrm{~m}, \geq 0.30 \mathrm{~m}$ and $<1.37 \mathrm{~m}$, or $\geq 1.37 \mathrm{~m})$ on the 0.0004 ha plots. On the 0.004 and 0.02 ha plots, trees were classified by species, dbh, origin, and crown class. All trees within a discernable overstory were classified as either dominant, co-dominant, intermediate, or overtopped, according to the Kraft Crown Classification system (Smith et al., 1997). Stems that contained crowns at least $3 \mathrm{~m}$ below the 
overstory canopy were classified as understory. Depending on the size and shape of each clearcut, plots were established at a rate of 7.4 to 9.9 per ha.

\section{Data Analysis}

Preharvest stand conditions (trees per hectare and basal area per hectare) were determined from the $100 \%$ inventories conducted immediately prior to each harvest. In the year 2000, mean trees per hectare and mean basal area per hectare were calculated from sample plots for each species in each stand. Relative number of trees per hectare and relative basal area per hectare were used to calculate species importance values (IV) for each crown class and canopy strata.

$$
\text { Species IV }=\frac{\% \text { Trees per Hectare }+\% \text { Basal Area per Hectare }}{2}
$$

Detrended correspondence analysis (DCA) (Hill and Gauch, 1980) of IV was used to examine the relationship of preharvest and postharvest stands according to their species composition. DCA arranges vegetation samples according to similarities in species composition (Kent and Coker, 1994). Several site variables were examined to assess if they were associated with the arrangement of postharvest stands. Site variables tested include stand age, harvest size, aspect, slope, and soil type.

The Shannon-Weaver Diversity Index (H') (Shannon and Weaver, 1949), Pielou's evenness index (E) (Pielou, 1969), and species richness (S) were calculated for pre and postharvest stand structures for 12 of the harvest areas. These values were calculated for all trees and additionally, for preharvest overstory trees $(\geq 25.4 \mathrm{~cm})$ and postharvest overstory trees in stands $\geq 12$ years old. Preharvest H', E, and S could not be calculated for stand 10 , because of missing inventory data. $\mathrm{S}$ is the total number of species present on a given stand. E is a measure of the evenness of species abundance. $\mathrm{H}^{\prime}$ is a function 
of both species richness and evenness. H' was calculated based on species importance values by using the following equation: $H^{\prime}=-p_{i} \ln p_{i}$, where $p_{i}$ is the proportion of importance of the $i^{\text {th }}$ species. E was calculated as $E=H^{\prime} / \ln$ (richness). A paired-sample t-test (Kent and Coker, 1994) was used to compare species diversity, evenness, and richness for pre and postharvest samples.

\section{Results}

\section{Preharvest Stand Structure}

Twenty-three species were present on the sites prior to clearcutting. Sugar maple, yellow-poplar, American basswood, American beech, and northern red oak were the most important species throughout the sites (Table 1). Species such as black cherry, black locust, hickory, red elm, red maple, white ash, and yellow birch were locally abundant on some areas. Other species present included black birch, butternut, black walnut, chestnut oak, cucumber magnolia, flowering dogwood, fire cherry, ironwood, sassafras, downy serviceberry, and white oak. Stands contained an average of $280( \pm 15)$ trees/ha and $30.45( \pm 1.86) \mathrm{m}^{2}$ of basal area/ha.

Overstories were typically dominated by varying proportions of yellow-poplar, sugar maple, American basswood, American beech, and northern red oak. Other common overstory species included black cherry, black locust, hickory, red elm, and white ash (Table 2). The understory and advanced regeneration in all harvest areas was dominated by sugar maple and American beech (Tables 2 and 3).

Prior to clearcutting, the average number of species present was 14 and average H' was 2.068. Species evenness averaged 0.797. Species richness on a site ranged from 
7 in stand 13 to 21 in stand 2. Species diversity was just as variable; it ranged from a low of 1.681 in stand 4 to a high of 2.401 in stand 2. Species evenness ranged from 0.698 in stand 1 to 0.864 in stand 13 (Table 4).

\section{Postharvest Stand Structure}

\section{Species Composition}

Of the 26 species regenerating after clearcutting, yellow-poplar and sugar maple were the only species present in all 13 stands. American beech, American basswood, black birch, black cherry, black locust, cucumber magnolia, devils-walkingstick (Aralia spinosa), fire cherry, hickory, red elm, red maple, northern red oak, striped maple, and white ash were common to most stands. Species found infrequently include alternate-leaf dogwood (Cornus alternifolia), butternut, chestnut oak, flowering dogwood, ironwood, American hornbeam (Carpinus caroliniana), sassafras, staghorn sumac (Rhus typhina), white oak, and yellow birch (Table 5).

In 2-6 year old stands, $77 \%$ of the regeneration (based on importance values) is contained in 5 species: yellow-poplar (24\%), sugar maple (19\%), black birch (16\%), striped maple (11\%), and American basswood (7\%). Striped maple is only abundant in one stand, the other four species were highly important in all stands of this age class. These young stands contain an average of 49,148 $( \pm 8,885)$ trees/ha and a very minimal amount of basal area (Table 4). Stands had a wide range in stem density primarily due to the amount of herbaceous competition present. Twenty five percent of the basal area is contained in yellow-poplar. The most numerous species found are sugar maple (26\%), followed closely by black birch (23\%) and yellow-poplar (22\%). The high amount of sugar maple is attributed to the abundance of sugar maple advanced regeneration 
inventoried at the time of harvest. Fifty two percent of the advanced regeneration immediately prior to clearcutting was sugar maple (Table 3). Four species, alternate-leaf dogwood, chestnut oak, sassafras, and white oak were found exclusively in these youngest stands (Table 6).

In stands $\geq 12$ years old, the most important species are yellow-poplar and sugar maple. The 12-16 year old stands averaged 10,591 $( \pm 684)$ trees/ha and $15.59( \pm 0.74)$ $\mathrm{m}^{2}$ of basal area/ha. The 22-26 year old stands averaged 8,605 $( \pm 2828)$ trees/ha and $24.55( \pm 2.18) \mathrm{m}^{2}$ of basal area/ha (Table 4). The stem density in stand 12 is much higher than the other stands in this age class because of a dense understory of sugar maple. In both age classes, sugar maple had the highest density of stem/ha (31\% - 47\%) and yellow-poplar occupied the most basal area $(31 \%-53 \%)$. Basal area of black locust was second highest (18\%) in 12-16 year old stands, and black cherry basal area was second highest (15\%) in the oldest stands. American basswood was ranked third in terms of basal area in stands $\geq 12$ years old (Table 6 ).

Yellow-poplar shows a progressive increase in IV and relative basal area as stand age increases. Alternatively, black birch, a species that aggressively invades clearcuts, decreased in importance over time as yellow-poplar became more dominant. Black birch IV averaged $16 \%$ in the youngest stands decreasing to $6 \%$ and $2 \%$ in $12-16$ and $22-26$ year old stands, respectively (Table 6). Northern red oak, chestnut oak, and white oak are completely absent from stands $\geq 12$ years old, except for northern red oak seedlings and one overtopped stem (Table 2) found in stands $\geq 22$ years old. 


\section{Species Diversity and Richness}

Overall, the average number of species present after clearcutting is 13 and $\mathrm{H}^{\prime}$ averaged 1.826, which are slightly less than the average, found prior to harvesting. Species evenness averaged 0.711 in the postharvest stands. Species richness ranged from 7 species in stand 4 to 21 species in stand 2 . $\mathrm{H}^{\prime}$ values ranged from 1.357 in stand 4 to 2.443 in stand 7. E was highest in stand 7 (0.881), and lowest in stand 8 (0.611) (Table 4).

\section{Canopy Structure}

The overstory of stands $\geq 12$ years old are primarily dominated by yellow-poplar. Sugar maple and American basswood also are an important component of these overstories. Other species with high overstory importance include black locust and black birch in the 12-16 year old stands and black cherry in the oldest stands. Yellow-poplar and black locust are the most important species in the dominant crown class and yellowpoplar, black locust, American basswood, black cherry, and black birch are important in the co-dominant class. Yellow-poplar, sugar maple, American basswood, and black birch also are important in the intermediate crown class. Sugar maple dominates the overtopped crown class and the understory. Northern red oak, chestnut oak, and white oak are completely absent from dominant, co-dominant, and intermediate crown classes (Table 2).

The 2-6 year old stands are still in the stand initiation stage (Oliver and Larson, 1996) and have not yet developed stratified canopies. Therefore, seedling/sapling height classes were used to infer future canopy development. Stems in the smallest height class $(<.31 \mathrm{~m}$ tall) are dominated by sugar maple and yellow-poplar. Stems $\geq .31 \mathrm{~m}$ are 
primarily black birch, sugar maple, and yellow-poplar (Table 2). Yellow-poplar dominated stems $\geq 2.54 \mathrm{~cm}$ dbh in these stands (Tables 7 and 8).

The chronosequence of stands shows a pattern of species dominance shifts over time. In stands 2-6 years old, yellow-poplar has a 16\% IV in the largest stems $(\geq 1.37$ $\mathrm{m})$, increasing to a $26 \%$ overstory IV in $12-16$ year old stands. The highest yellowpoplar overstory IV is in stands $22-26$ years old, where it is greater than $43 \%$. Black birch shows just the opposite pattern. The highest black birch IV is in the youngest stands where stems $\geq 1.37 \mathrm{~m}$ have an IV of $41 \%$. In the overstory of stands $12-16$, and 22-26 years old, black birch's IV is only $8 \%$ and 5\%, respectively. Black birch primarily occupies an intermediate crown position in these older stands, whereas in the youngest stands it is one of the most dominant species. Yellow-poplar shows early dominance and continues to increase in dominance over time.

\section{Comparison of Preharvest and Postharvest Structures}

The DCA of preharvest and postharvest stands indicate that preharvest stands are more similar than postharvest stands. Variability between stands was much higher after clearcutting than before. The first axis (eigenvalue $=0.2399$ ) was most positively correlated with black birch $(r=0.641)$ and striped maple $(r=0.612)$, and most negatively correlated with yellow poplar $(\mathrm{r}=-0.632)$ and yellow birch $(\mathrm{r}=-0.531)$. The second axis (eigenvalue $=0.1093)$ was most negatively correlated with sugar maple $(\mathrm{r}=-0.688)$ and red elm $(r=-0.680)$. The third axis accounted for little of the variation in the ordination $($ eigenvalue $=0.0751)($ Figure 2$)$

Results from the DCA of postharvest stands indicate that stand age, harvest size, aspect, slope, and soil type were not associated with the arrangement of stands in the 
ordination. The high IV of yellow-poplar and sugar maple had the greatest effect on how the stands were separated. The first axis (eigenvalue $=0.2859$ ) was most positively correlated with yellow-poplar $(\mathrm{r}=0.835)$ and white ash $(\mathrm{r}=0.795)$ and most negatively correlated with sugar maple $(r=-0.622)$, striped maple $(r=-0.596)$, and black birch $(r=-$ 0.539). The second axis (eigenvalue $=0.2012$ ) was most positively correlated with American basswood $(r=0.638)$ and most negatively correlated with red elm $(r=-0.795)$ and sugar maple $(\mathrm{r}=-0.599)$. The third axis accounted for little of the variation in the ordination (eigenvalue $=0.0383)($ Figure 3$)$.

Based on species importance values, three general groups can be seen in the DCA ordination: 1) high yellow-poplar, 2) high sugar maple, and 3) high black birch. Stands $4,6,11$, and 13 were grouped together (Group 1) because they all have high importance of yellow-poplar. Stands 6 and 13 also have high importance of white ash. The second group consists of stands $1,8,9,10$, and 12 , which have high importance values of sugar maple. Stands 8 and 9 are separated slightly because they also have high importance values of red elm. The third group consists of stands $2,3,5$, and 7 , which all have high importance values of black birch. Stand 2 is separated from the rest of this grouping because it contains high importance of American basswood (Figure 3).

Results from the paired-sample t-test indicate that species diversity 2-26 years after clearcutting was significantly different $(.005>p>.001)$ from preharvest stands. The average $\mathrm{H}^{\prime}$ immediately prior to harvesting was 2.068 and after harvest the average was reduced to 1.826 . Species richness decreased after clearcutting as well, but only slightly. Before harvesting species richness averaged about 14 species per stand. After clearcutting S decreased to 13 species per stand. The species richness following 
clearcutting was not significantly different $(.20>p>.10)$ from that prior to clearcutting. Species evenness significantly decreased $(.005>\mathrm{p}>.001)$ from 0.797 prior to harvest to 0.711 after the harvest.

As stands continued development through stem exclusion, aggressive growth by a few species created overstory canopies with lower species diversity, evenness, and richness then in preharvest overstories. The average overstory H' prior to clearcutting was 2.024 decreasing to 1.660 after clearcutting. A paired-sample t-test indicated that the overstories of stands $\geq 12$ years old were significantly less diverse $(.025>\mathrm{p}>.01)$ than the overstory of those areas immediately prior to harvesting. The species richness of the overstory decreased from 12.1 species to 11.1 species $12-26$ years after the clearcutting, but was not significantly less $(.25>p>.10)$ than prior to clearcutting. However, species evenness in the overstory significantly decreased $(.025>\mathrm{p}>.01)$ from $0.825 \mathrm{in}$ preharvest stands to 0.686 in postharvest stands.

\section{Discussion}

Clearcutting second-generation Appalachian hardwood forests has reduced species diversity and evenness in the developing cohort. As soon as 12 years after clearcutting, the third-generation forest overstory is dominated by yellow-poplar, with lesser amounts of American basswood, black locust, sugar maple, and black birch (Figure 3). Silvicultural clearcutting creates environmental conditions that favor the establishment and growth of shade intolerant species (Smith et al., 1997). Development of the second-generation forest was strongly influenced by the partial disturbances of chestnut blight and harvesting, which allowed shade tolerant species like sugar maple and 
American beech to become major overstory components along with yellow-poplar, American basswood, and northern red oak. If the management objective had been to produce third-generation stands with the same composition and structure as those they replaced, then a series of partial harvests, creating a range in size of canopy openings, should have been used to mimic the original disturbance pattern (Trimble, 1973).

While the species richness of the new stands was similar to the preharvest forest, a change in species diversity and evenness following clearcutting is evident. Species diversity decreased in 11 out of the 12 stands in this study. The maintenance of species richness yet a decrease in species diversity can be explained by a decrease in species evenness. Overall, the number of species present before harvesting is equal to that present after harvesting. The decrease in evenness after harvesting was the result of the increases (yellow-poplar, black birch) or decreases (northern red oak, American beech) in the proportion of certain species. Similar species shifts have been noted in other eastern hardwood stands (Elliot et al., 1997; Elliott and Swank, 1994; Hibbs, 1983). Species such as northern red oak and chestnut oak were not found in 4 stands where they occurred prior to clearcutting, and species such as fire cherry (7 stands), devil's walking stick (8 stands), and striped maple (8 stands) aggressively colonized stands where they had no preharvest presence (Tables 1 and 5).

Other studies of young ( $\leq 7$ years old) stand development after clearcutting have suggested that shade tolerant advanced regeneration of sugar maple and red maple may interfere with the height growth of shade intolerant species (Arthur et al., 1997; Trimble, 1972; Trimble, 1973). In our young stands, the presence of abundant sugar maple advanced regeneration did not delay the rapid emergence of shade intolerant species. 
Sugar maple composed the majority of the advanced regeneration (52\%) and had a high IV (19\%) following clearcutting. However, yellow-poplar and black birch seedlings have the highest importance of the tallest stems and are already expressing dominance at this young age regardless of sugar maple's presence. Even though sugar maple is the most abundant species, it is more important in the smaller stems.

As these stands progress through the stem exclusion stage, $\mathrm{H}^{\prime}, \mathrm{S}$, and $\mathrm{E}$ are expected to continue declining as yellow-poplar increases in dominance. Once yellowpoplar has expressed dominance in the overstory of a stand, it will continue rapid height growth until age 30 (Beck, 1990). Alternatively, black birch is decreasing in importance in these stands, which is typical of this forest type (Beck and Hooper, 1986). In the overstory, yellow-poplar dominates the upper crown classes whereas black birch has generally been reduced to an intermediate crown position. Black birch grows very rapidly following a disturbance, yet usually succumbs to competition by the age of 20 (Lamson, 1990). Compared to preharvest stands, black locust has a much higher overstory importance, especially in the dominant crown class. After age 30, black locust height growth is expected to rapidly decline (Huntley, 1990), along with a decrease in black locust importance as it succumbs to competition. Sugar maple, has the second highest IV in stands $\geq 12$ years old, only because of numerous stems in the overtopped crown class and understory. Sugar maple will decrease in overstory importance, but will remain a major stand component due to high shade tolerance and longevity. American basswood, a species with a high propensity to sprout (Crow, 1991), has been able to maintain its overstory component due to this ability. Eighty-nine percent of the American basswood stems in the overstory were of sprout origin (Table 9). 
A dramatic reduction in northern red oak was observed in the older postharvest stands. Immediately following clearcutting, in stands 2-6 years old, northern red oak contains numerous stems in competitive positions. In these youngest stands, northern red oak is the fourth most abundant species (6\%), has over $8 \%$ of the stems $\geq 0.31 \mathrm{~m}-<1.37$ $\mathrm{m}$ tall, and $4 \%$ of the tallest stems. In stands $\geq 12$ years old, this species, which had composed about $10 \%$ of the preharvest overstory, is nearly absent. The loss of northern red oak on high quality sites after clearcutting is primarily due to the lack of advanced regeneration (Loftis, 1990) [only $2 \%$ of the advanced regeneration present before harvest was northern red oak (Table 3 ) and only $3 \%$ of the northern red oak stems that regenerated after harvesting were sprouts (Table 9)] and its inability to compete with more aggressive species like yellow-poplar, black birch, and black locust (Beck and Hooper, 1986). In order to maintain a northern red oak component in stands similar to these, some type of cultural treatment should be performed between the ages of 6-10 (Beck and Hooper, 1986). After this point the competitive northern red oak stems have succumbed to superior competition.

Traditional studies of stand development after disturbance typically use IV, relative trees/ha, and relative basal area/ha to determine the future development of a forest. After clearcutting, Appalachian hardwood stands follow the single-cohort mixed species development model (Oliver and Larson, 1996) where species assemble in various canopy strata according to their silvical characteristics. As the canopy stratifies, fast growing species like yellow-poplar can achieve and maintain overstory dominance. The strength of yellow-poplar's dominance is masked when only stand level IV, relative trees/ha, or relative basal area/ha are examined. For example, yellow-poplar's 
importance in the oldest stands is $30 \%$, whereas yellow-poplar's IV in the dominant and co-dominant crown class is $50 \%$ and $43 \%$, respectively. Alternatively, sugar maple's importance for all trees in the oldest stands is $26 \%$, whereas in the dominant and codominant crown classes its IV is $<1 \%$.

Clearcutting creates environmental conditions favorable to the rapid, early height growth of yellow poplar seedlings. In our study, yellow-poplar dominates the overstory of all stands, and has influenced the reduction or loss of species such as northern red oak. Shade tolerant American basswood maintained overstory status only because of its ability to sprout. Sugar maple, another shade tolerant species, will persist in the understory and attain overstory status at a rate functionally related to future canopy disturbance levels. Postharvest stands are more homogeneous than the preharvest forest. As stand development progresses, the stands will be ultimately dominated by yellow-poplar, American basswood, and sugar maple. 


\section{Literature Cited}

Arthur, M.A., R.N. Muller, and S. Costello. 1997. Species composition in a central hardwood forest in Kentucky 11 years after clear-cutting. American Midland Naturalist, 137: 274-281.

Beck, D.E. 1990 Liriodendron tulipifera L. Yellow-Poplar. In: R.M. Burns and B. H. Honkala, eds., Silvics of North America. Volume 2. Hardwoods. USDA Forest Service Agriculture Handbook No. 654, pp. 406-416.

Beck, D.E. and R.M. Hooper. 1986. Development of a Southern Appalachian hardwood stand after clearcutting. Southern Journal of Applied Forestry, 10:168-172.

Braun, L.E. 1950. Deciduous forests of eastern North America. The Blakiston Co., Philadelphia. 556 pp.

Crow, T.R., 1990. Tilia americana L. American Basswood. In: R.M. Burns and B. H. Honkala, eds., Silvics of North America. Volume 2. Hardwoods. USDA Forest Service Agriculture Handbook No. 654, pp. 784-791.

Dale, M.E., H.C. Smith, and J.N. Pearcy. 1995. Size of clearcut opening affects species composition, growth rate, and stand characteristics. USDA Forest Service Research Paper NE-698.

DeMeo, T.L., T. Wright, and L. Wright. 1995. Landtype associations of the Monogahela National Forest. 1:250,000; UTM map projection. USDA Forest Service, Monongahela National Forest.

Elliott, K.J. and W.T. Swank. 1994. Changes in tree species diversity after successive clearcuts in the southern Appalachians. Vegetation, 115:11-18.

Elliott, K.J., L.R. Boring, W.T. Swank, and B.R. Haines. 1997. Successional changes in plant species diversity and composition after clearcutting a southern Appalachian watershed. Forest Ecology and Management, 92:67-85.

Hibbs, D.E. 1983. Forty year of forest succession in central New England. Ecology, 64(6):1394-1401.

Hicks, R.R. Jr. 1998. Ecology and management of central hardwood forests. John Wiley \& Sons. New York, USA.

Hill, M.O. and H.E. Gauch. 1980. Detrended correspondence analysis, an improved ordination technique. Vegetatio. 42: 47-58. 
Huntley, J.C., 1990. Robinia pseudoacacia L. Black Locust. In: R.M. Burns and B. H. Honkala, eds., Silvics of North America. Volume 2. Hardwoods. USDA Forest Service Agriculture Handbook No. 654, pp.755-761.

Kent, M. and P. Coker. 1992. Vegetation Description And Analysis; A Practical Approach. John Wiley \& Sons. New York, USA.

Lamson, N.I. 1990. Betula lenta L. Sweet Birch. In: R.M. Burns and B. H. Honkala, eds., Silvics of North America. Volume 2. Hardwoods. USDA Forest Service Agriculture Handbook No. 654, pp. 148-152.

Loftis, D.L. 1990. A shelterwood method for regeneration red oak in the southern Appalachians. Forest Science 36: 917-929.

Losche, C.R. and W.W. Beverage. 1967. Soil survey of Tucker County and part of northern Randolph County, West Virginia. USDA Soil Conservation and Forest Service. Washington, D.C.

Marks, P.L. 1973. The role of pin cherry (Prunus pennsylvanica L.) in the maintenance of stability in northern hardwood ecosystems. Ecological Monographs 44(1): 73-88.

Marquis, D.A. 1967. Clearcutting in northern hardwoods: results after 30 years. USDA Forest Service Research Paper NE-85.

McNab, W.H and P.E. Avers. 1994. Ecological subregions of the United States: section descriptions. USDA Forest Service. Washington, D.C.

Miller, G.W. and J.N. Kochenderfer.1998. Maintaining species diversity in the central Appalachians. Journal of Forestry, 96(7): 28-33.

Nyland, R.D. 1996. Silviculture: concepts and applications. The McGraw-Hill Companies, New York.

Oliver, C.D., and B.C. Larson. 1996. Forest stand dynamics. John Wiley and Sons, New York.

Pan, C., S.J. Tajchman, and J.N. Kochenderfer. 1997. Dendroclimatological analysis of major forest species of the central Appalachians. Forest Ecology and Management 98: 77-87.

Parker, G.R. and W.T. Swank. 1982. Tree species response to clear-cutting a southern Appalachian watershed. The American Midland Naturalist, p.304-310.

Pielou, E.C. 1969. An introduction to mathematical ecology. New York: John Wiley and Sons. 
Perala, D.A. 1990. Populus tremuloides Michx. Quaking Aspen In: R.M. Burns and B. H. Honkala, eds., Silvics of North America. Volume 2. Hardwoods. USDA Forest Service Agriculture Handbook No. 654, pp. 555-569.

Schuler, T.M. 1998. Patterns of oak regeneration in a central Appalachian forest. Ph.D. Dissertation. Purdue University, West Lafayette, IN.

Shannon, C.E. and Weaver, W. 1949. The mathematical theory of communication. University of Illinois Press, Urbana.

Smith, D.M., B.C. Larson, M.J. Kelly, and P.M.S. Ashton. 1997. The practice of silviculture: applied forest ecology. John Wiley and Sons, New York.

Smith, H.C., L. Della-Bianca, and H. Fleming. 1983. Appalachian mixed hardwoods In: R.M. Burns ed., Silvicultural systems for the major forest types of the United States. USDA Forest Service Agricultural Handbook No. 445, pp. 141-144.

Trimble, G.R. Jr. 1977. A history of the Fernow Experimental Forest and the Parsons Timber and Watershed Laboratory. USDA Forest Service General Technical Report NE-28.

Trimble, G.R. Jr. 1972. Reproduction 7 years after seed-tree harvest cutting in Appalachian hardwoods. USDA Forest Service Research Paper NE-223 19p.,illus.

Trimble, G.R. Jr. 1973. The regeneration of central Appalachian hardwoods with emphasis on the effect of site quality and harvesting practice. USDA Forest Service Research Paper NE-282.

Trimble, G.R. Jr. and George Hart. 1961. An appraisal of early reproduction after cutting in northern Appalachian hardwood stands. Station Paper No. 162. Northeast Forest Experimental Station.

Walters, R.S. and R.D. Nyland. 1989. Clearcutting central New York northern hardwood stands. Northern Journal of Applied Forestry, 6:75-78.

Wang, Z. and R.D. Nyland. 1996. Changes in the condition and species composition of developing even-aged northern hardwood stands in central New York. Northern Journal of Applied Forestry, 13(4):189-194.

Wang, Z. and R.D. Nyland. 1993. Tree species richness increased by clearcutting of northern hardwoods in central New York. Forest Ecology and Management, 57:7184.

Weitzman, S. 1949. The Fernow Experimental Forest. Upper Darby, PA: U.S. Department of Agriculture, Forest Service, Northeastern Forest Experiment Station. 
Wendel, G.W. 1990. Prunus pensylvanica L.F. Pin Cherry. In: R.M. Burns and B. H. Honkala, eds., Silvics of North America. Volume 2. Hardwoods. USDA Forest Service Agriculture Handbook No. 654, pp. 587-593. 
Table 1: Preharvest Species Composition, Relative Trees per Hectare ( $\mathrm{rt} / \mathrm{ha}$ ), Relative Basal Area per Hectare ( $\mathrm{r}$ ba/ha), and Relative Importance Value (riv)

\begin{tabular}{|c|c|c|c|c|c|c|c|c|c|c|c|c|c|c|c|c|c|c|c|c|c|}
\hline \multirow[b]{3}{*}{ Species } & \multicolumn{21}{|c|}{ Stands } \\
\hline & \multicolumn{3}{|c|}{ All Stands } & \multicolumn{3}{|c|}{1} & \multicolumn{3}{|c|}{2} & \multicolumn{3}{|c|}{3} & \multicolumn{3}{|c|}{4} & \multicolumn{3}{|c|}{5} & \multicolumn{3}{|c|}{6} \\
\hline & $\mathrm{rt}$ /ha & $\mathrm{rba} / \mathrm{ha}$ & riv & $\mathrm{rt} / \mathrm{ha}$ & $\mathrm{rba} / \mathrm{ha}$ & $\mathrm{riv}$ & $\mathrm{rt} / \mathrm{ha}$ & $\mathrm{rba} / \mathrm{ha}$ & $\mathrm{riv}$ & $\mathrm{rt} / \mathrm{ha}$ & $\mathrm{rba} / \mathrm{ha}$ & $\mathrm{riv}$ & $\mathrm{rt} / \mathrm{ha}$ & $\mathrm{rba} / \mathrm{ha}$ & riv & $\mathrm{rt} / \mathrm{ha}$ & $\mathrm{rba} / \mathrm{ha}$ & $\mathrm{riv}$ & $\mathrm{rt}$ /ha & $\mathrm{rba} / \mathrm{ha}$ & $\mathrm{riv}$ \\
\hline sugar maple & 29.2 & 20.7 & 24.9 & 47.6 & 28.0 & 37.8 & 14.8 & 9.1 & 12.0 & 22.5 & 15.9 & 19.2 & 39.9 & 26.0 & 32.9 & 24.1 & 14.5 & 19.3 & 47.0 & 31.4 & 39.2 \\
\hline yellow poplar & 12.4 & 20.6 & 16.5 & 3.4 & 8.7 & 6.0 & 14.1 & 22.4 & 18.2 & 9.9 & 13.7 & 11.8 & 18.2 & 32.1 & 25.1 & 13.9 & 32.4 & 23.2 & 4.4 & 10.4 & 7.4 \\
\hline American basswood & 15.3 & 14.3 & 14.8 & 22.7 & 24.6 & 23.6 & 1.5 & 1.1 & 1.3 & 16.6 & 14.4 & 15.5 & 18.2 & 17.8 & 18.0 & 13.9 & 10.9 & 12.4 & 18.2 & 20.5 & 19.4 \\
\hline American beech & 9.5 & 8.9 & 9.2 & 3.5 & 3.4 & 3.5 & 19.2 & 10.3 & 14.8 & 20.2 & 20.4 & 20.3 & 2.1 & 1.1 & 1.6 & 6.5 & 5.4 & 6.0 & 7.2 & 6.9 & 7.1 \\
\hline northern red oak & 5.3 & 10.2 & 7.8 & 4.0 & 11.5 & 7.8 & 7.7 & 18.3 & 13.0 & 7.6 & 17.8 & 12.7 & 0.0 & 0.0 & 0.0 & 6.5 & 15.3 & 10.9 & 1.1 & 1.8 & 1.5 \\
\hline hickory & 4.2 & 4.6 & 4.4 & 2.0 & 2.9 & 2.5 & 2.9 & 4.2 & 3.5 & 4.0 & 3.8 & 3.9 & 0.7 & 1.4 & 1.0 & 3.7 & 3.5 & 3.6 & 6.1 & 7.0 & 6.5 \\
\hline red elm & 2.8 & 3.7 & 3.2 & 2.7 & 2.1 & 2.4 & 0.3 & 0.3 & 0.3 & 0.0 & 0.0 & 0.0 & 7.7 & 13.1 & 10.4 & 0.0 & 0.0 & 0.0 & 5.5 & 9.6 & 7.5 \\
\hline black cherry & 2.3 & 3.9 & 3.1 & 7.2 & 13.4 & 10.3 & 5.4 & 7.0 & 6.2 & 0.7 & 0.8 & 0.7 & 0.0 & 0.0 & 0.0 & 1.9 & 3.2 & 2.5 & 0.8 & 1.9 & 1.3 \\
\hline black birch & 3.4 & 1.9 & 2.7 & 1.0 & 1.0 & 1.0 & 7.0 & 5.1 & 6.0 & 5.0 & 2.3 & 3.7 & 0.0 & 0.0 & 0.0 & 4.6 & 2.3 & 3.5 & 1.1 & 1.2 & 1.1 \\
\hline yellow birch & 3.5 & 1.7 & 2.6 & 0.3 & 0.6 & 0.5 & 0.6 & 0.3 & 0.4 & 0.0 & 0.0 & 0.0 & 9.1 & 5.3 & 7.2 & 9.3 & 3.6 & 6.5 & 2.2 & 0.9 & 1.6 \\
\hline white ash & 2.3 & 2.8 & 2.6 & 1.3 & 1.8 & 1.6 & 3.8 & 6.2 & 5.0 & 0.3 & 0.0 & 0.2 & 4.2 & 3.2 & 3.7 & 1.9 & 1.5 & 1.7 & 4.7 & 7.1 & 5.9 \\
\hline cucumber magnolia & 2.8 & 2.0 & 2.4 & 1.0 & 0.7 & 0.9 & 2.4 & 1.9 & 2.2 & 3.0 & 2.6 & 2.8 & 0.0 & 0.0 & 0.0 & 8.3 & 4.3 & 6.3 & 1.1 & 0.8 & 1.0 \\
\hline red maple & 2.5 & 1.6 & 2.0 & 0.7 & 0.6 & 0.6 & 15.1 & 9.0 & 12.0 & 3.6 & 2.3 & 2.9 & 0.0 & 0.0 & 0.0 & 1.9 & 1.8 & 1.8 & 0.0 & 0.0 & 0.0 \\
\hline black locust & 2.3 & 1.7 & 2.0 & 0.2 & 0.3 & 0.2 & 1.1 & 0.8 & 0.9 & 2.3 & 1.6 & 2.0 & 0.0 & 0.0 & 0.0 & 2.8 & 1.2 & 2.0 & 0.3 & 0.5 & 0.4 \\
\hline chestnut oak & 0.7 & 0.7 & 0.7 & 0.0 & 0.0 & 0.0 & 0.8 & 0.9 & 0.8 & 3.3 & 4.0 & 3.7 & 0.0 & 0.0 & 0.0 & 0.0 & 0.0 & 0.0 & 0.0 & 0.0 & 0.0 \\
\hline ironwood & 0.9 & 0.2 & 0.6 & 2.4 & 0.4 & 1.4 & 0.9 & 0.2 & 0.5 & 0.3 & 0.1 & 0.2 & 0.0 & 0.0 & 0.0 & 0.0 & 0.0 & 0.0 & 0.3 & 0.1 & 0.2 \\
\hline white oak & 0.2 & 0.4 & 0.3 & 0.0 & 0.0 & 0.0 & 0.8 & 2.5 & 1.6 & 0.0 & 0.0 & 0.0 & 0.0 & 0.0 & 0.0 & 0.0 & 0.0 & 0.0 & 0.0 & 0.0 & 0.0 \\
\hline downy serviceberry & 0.2 & 0.0 & 0.1 & 0.0 & 0.0 & 0.0 & 0.5 & 0.1 & 0.3 & 0.7 & 0.1 & 0.4 & 0.0 & 0.0 & 0.0 & 0.9 & 0.2 & 0.5 & 0.0 & 0.0 & 0.0 \\
\hline flowering dogwood & 0.1 & 0.0 & 0.1 & 0.0 & 0.0 & 0.0 & 0.0 & 0.0 & 0.0 & 0.0 & 0.0 & 0.0 & 0.0 & 0.0 & 0.0 & 0.0 & 0.0 & 0.0 & 0.0 & 0.0 & 0.0 \\
\hline butternut & 0.0 & 0.1 & 0.0 & 0.0 & 0.0 & 0.0 & 0.0 & 0.0 & 0.0 & 0.0 & 0.0 & 0.0 & 0.0 & 0.0 & 0.0 & 0.0 & 0.0 & 0.0 & 0.0 & 0.0 & 0.0 \\
\hline fire cherry & 0.0 & 0.0 & 0.0 & 0.0 & 0.0 & 0.0 & 0.6 & 0.1 & 0.4 & 0.0 & 0.0 & 0.0 & 0.0 & 0.0 & 0.0 & 0.0 & 0.0 & 0.0 & 0.0 & 0.0 & 0.0 \\
\hline sassafras & 0.0 & 0.0 & 0.0 & 0.0 & 0.0 & 0.0 & 0.5 & 0.1 & 0.3 & 0.0 & 0.0 & 0.0 & 0.0 & 0.0 & 0.0 & 0.0 & 0.0 & 0.0 & 0.0 & 0.0 & 0.0 \\
\hline black walnut & 0.0 & 0.0 & 0.0 & 0.0 & 0.0 & 0.0 & 0.2 & 0.2 & 0.2 & 0.0 & 0.0 & 0.0 & 0.0 & 0.0 & 0.0 & 0.0 & 0.0 & 0.0 & 0.0 & 0.0 & 0.0 \\
\hline
\end{tabular}

${ }^{a}$ Pre-harvest data not available for stand 10 
Table 1: Preharvest Species Composition, Relative Trees per Hectare ( $r$ t/ha), Relative Basal Area per Hectare ( $\mathrm{r}$ ba/ha), and Relative Importance Value (riv)

\begin{tabular}{|c|c|c|c|c|c|c|c|c|c|c|c|c|c|c|c|c|c|c|c|}
\hline \multirow[b]{3}{*}{ Species } & \multicolumn{19}{|c|}{ Stands } \\
\hline & \multicolumn{3}{|c|}{7} & \multicolumn{3}{|c|}{8} & \multicolumn{3}{|c|}{9} & \multirow[t]{2}{*}{$10^{\mathrm{a}}$} & \multicolumn{3}{|c|}{11} & \multicolumn{3}{|c|}{12} & \multicolumn{3}{|c|}{13} \\
\hline & $r$ t/ha & $\mathrm{rba} / \mathrm{ha}$ & riv & $\mathrm{rt} / \mathrm{ha}$ & $\mathrm{rba} / \mathrm{ha}$ & $r$ iv & $\mathrm{rt} / \mathrm{ha}$ & $\mathrm{rba} / \mathrm{ha}$ & $r$ iv & & $r$ t/ha & $\mathrm{rba} / \mathrm{ha}$ & $r$ iv & $r$ t/ha & $\mathrm{rba} / \mathrm{ha}$ & $r$ iv & $\mathrm{rt} / \mathrm{ha}$ & $\mathrm{rba} / \mathrm{ha}$ & riv \\
\hline sugar maple & 27.4 & 20.0 & 23.7 & 14.4 & 18.3 & 16.3 & 14.1 & 22.2 & 18.2 & $n / a$ & 39.2 & 21.7 & 30.4 & 15.6 & 17.9 & 16.7 & 25.2 & 16.1 & 20.6 \\
\hline yellow poplar & 4.4 & 7.0 & 5.7 & 14.7 & 19.5 & 17.1 & 18.5 & 29.9 & 24.2 & $\mathrm{n} / \mathrm{a}$ & 10.1 & 16.0 & 13.0 & 20.5 & 27.2 & 23.8 & 26.0 & 39.9 & 33.0 \\
\hline American basswood & 15.9 & 16.7 & 16.3 & 5.4 & 4.3 & 4.8 & 18.5 & 14.6 & 16.5 & $\mathrm{n} / \mathrm{a}$ & 3.8 & 3.1 & 3.4 & 23.4 & 14.2 & 18.8 & 17.9 & 18.7 & 18.3 \\
\hline American beech & 9.6 & 12.5 & 11.1 & 24.1 & 21.9 & 23.0 & 10.9 & 8.4 & 9.6 & $\mathrm{n} / \mathrm{a}$ & 1.9 & 1.1 & 1.5 & 14.6 & 20.8 & 17.7 & 0.0 & 0.0 & 0.0 \\
\hline northern red oak & 8.9 & 17.4 & 13.1 & 9.0 & 11.4 & 10.2 & 9.8 & 8.8 & 9.3 & $n / a$ & 6.0 & 12.5 & 9.3 & 4.9 & 6.2 & 5.5 & 0.0 & 0.0 & 0.0 \\
\hline red elm & 0.0 & 0.0 & 0.0 & 1.1 & 0.7 & 0.9 & 1.1 & 0.6 & 0.8 & $n / a$ & 6.8 & 9.2 & 8.0 & 0.0 & 0.0 & 0.0 & 8.1 & 10.5 & 9.3 \\
\hline black cherry & 1.1 & 2.3 & 1.7 & 2.5 & 4.1 & 3.3 & 0.0 & 0.0 & 0.0 & $\mathrm{n} / \mathrm{a}$ & 1.6 & 2.4 & 2.0 & 2.0 & 2.3 & 2.1 & 0.0 & 0.0 & 0.0 \\
\hline black birch & 4.8 & 3.9 & 4.4 & 9.0 & 2.9 & 6.0 & 6.5 & 2.2 & 4.3 & $\mathrm{n} / \mathrm{a}$ & 2.2 & 1.5 & 1.8 & 2.4 & 1.6 & 2.0 & 0.0 & 0.0 & 0.0 \\
\hline yellow birch & 0.4 & 0.4 & 0.4 & 0.0 & 0.0 & 0.0 & 4.3 & 1.5 & 2.9 & $n / a$ & 0.0 & 0.0 & 0.0 & 3.4 & 1.3 & 2.4 & 15.4 & 7.5 & 11.5 \\
\hline white ash & 0.0 & 0.0 & 0.0 & 2.5 & 3.5 & 3.0 & 2.2 & 1.4 & 1.8 & $\mathrm{n} / \mathrm{a}$ & 6.5 & 9.9 & 8.2 & 0.5 & 0.3 & 0.4 & 0.8 & 0.2 & 0.5 \\
\hline cucumber magnolia & 4.4 & 2.7 & 3.6 & 2.2 & 1.4 & 1.8 & 6.5 & 6.1 & 6.3 & $\mathrm{n} / \mathrm{a}$ & 0.8 & 0.5 & 0.7 & 5.4 & 3.8 & 4.6 & 0.0 & 0.0 & 0.0 \\
\hline red maple & 4.1 & 3.6 & 3.8 & 2.5 & 0.7 & 1.6 & 1.1 & 0.4 & 0.7 & $\mathrm{n} / \mathrm{a}$ & 0.8 & 0.8 & 0.8 & 2.4 & 0.8 & 1.6 & 0.0 & 0.0 & 0.0 \\
\hline chestnut oak & 3.7 & 3.5 & 3.6 & 0.7 & 0.6 & 0.7 & 0.0 & 0.0 & 0.0 & $\mathrm{n} / \mathrm{a}$ & 0.0 & 0.0 & 0.0 & 0.5 & 0.1 & 0.3 & 0.0 & 0.0 & 0.0 \\
\hline ironwood & 1.9 & 0.3 & 1.1 & 1.1 & 0.2 & 0.7 & 0.0 & 0.0 & 0.0 & $\mathrm{n} / \mathrm{a}$ & 1.9 & 0.5 & 1.2 & 1.0 & 0.3 & 0.6 & 0.0 & 0.0 & 0.0 \\
\hline white oak & 0.4 & 0.1 & 0.2 & 1.1 & 2.2 & 1.6 & 0.0 & 0.0 & 0.0 & $\mathrm{n} / \mathrm{a}$ & 0.0 & 0.0 & 0.0 & 0.0 & 0.0 & 0.0 & 0.0 & 0.0 & 0.0 \\
\hline downy serviceberry & 0.0 & 0.0 & 0.0 & 0.0 & 0.0 & 0.0 & 0.0 & 0.0 & 0.0 & $\mathrm{n} / \mathrm{a}$ & 0.3 & 0.1 & 0.2 & 0.0 & 0.0 & 0.0 & 0.0 & 0.0 & 0.0 \\
\hline flowering dogwood & 0.0 & 0.0 & 0.0 & 0.0 & 0.0 & 0.0 & 0.0 & 0.0 & 0.0 & $\mathrm{n} / \mathrm{a}$ & 0.8 & 0.2 & 0.5 & 0.5 & 0.1 & 0.3 & 0.0 & 0.0 & 0.0 \\
\hline butternut & 0.0 & 0.0 & 0.0 & 0.0 & 0.0 & 0.0 & 0.0 & 0.0 & 0.0 & $\mathrm{n} / \mathrm{a}$ & 0.3 & 0.8 & 0.5 & 0.0 & 0.0 & 0.0 & 0.0 & 0.0 & 0.0 \\
\hline fire cherry & 0.0 & 0.0 & 0.0 & 0.0 & 0.0 & 0.0 & 0.0 & 0.0 & 0.0 & $\mathrm{n} / \mathrm{a}$ & 0.0 & 0.0 & 0.0 & 0.0 & 0.0 & 0.0 & 0.0 & 0.0 & 0.0 \\
\hline sassafras & 0.0 & 0.0 & 0.0 & 0.0 & 0.0 & 0.0 & 0.0 & 0.0 & 0.0 & $\mathrm{n} / \mathrm{a}$ & 0.0 & 0.0 & 0.0 & 0.0 & 0.0 & 0.0 & 0.0 & 0.0 & 0.0 \\
\hline black walnut & 0.0 & 0.0 & 0.0 & 0.0 & 0.0 & 0.0 & 0.0 & 0.0 & 0.0 & $\mathrm{n} / \mathrm{a}$ & 0.0 & 0.0 & 0.0 & 0.0 & 0.0 & 0.0 & 0.0 & 0.0 & 0.0 \\
\hline
\end{tabular}


Table 2: Importance Values for each Age Class, Crown Class $^{a}$, and Canopy Strata ${ }^{b}$

\begin{tabular}{|c|c|c|c|c|c|c|c|c|c|c|c|c|c|c|c|c|c|}
\hline \multirow[b]{2}{*}{ Species } & \multicolumn{3}{|c|}{ 2-6 Years } & \multicolumn{6}{|c|}{ 12-16 Years } & \multicolumn{6}{|c|}{ 22-26 Years } & \multicolumn{2}{|c|}{ Pre-Harvest } \\
\hline & $<.31 \mathrm{~m}$ & $\geq .31 \mathrm{~m}-<1.37 \mathrm{~m}$ & $\geq 1.37 \mathrm{~m}$ & $\mathrm{D}$ & $C D$ & I & OT & OS & US & $\mathrm{D}$ & CD & I & OT & OS & US & os & US \\
\hline yellow poplar & 30.7 & 17.2 & 20.3 & 30.3 & 29.7 & 26.3 & 18.4 & 26.4 & 0.0 & 45.4 & 54.4 & 35.5 & 26.9 & 43.4 & 17.6 & 19.5 & 2.0 \\
\hline sugar maple & 35.1 & 20.9 & 15.5 & 0.0 & 9.6 & 17.0 & 25.8 & 14.4 & 51.1 & 0.0 & 1.6 & 5.9 & 34.3 & 13.2 & 37.9 & 19.4 & 58.8 \\
\hline black locust & 0.2 & 0.7 & 3.9 & 52.9 & 13.5 & 3.6 & 4.6 & 13.2 & 0.0 & 40.9 & 2.1 & 0.0 & 0.0 & 1.7 & 0.0 & 3.0 & 1.2 \\
\hline American basswood & 2.3 & 0.5 & 7.0 & 2.7 & 13.6 & 4.7 & 6.7 & 9.2 & 15.3 & 0.0 & 7.8 & 19.2 & 14.9 & 10.9 & 4.9 & 15.7 & 3.9 \\
\hline black birch & 9.1 & 25.5 & 24.4 & 2.8 & 8.1 & 12.7 & 5.9 & 7.5 & 0.0 & 0.0 & 5.0 & 10.3 & 3.6 & 5.0 & 0.0 & 2.0 & 1.9 \\
\hline red elm & 0.0 & 0.0 & 2.6 & 0.0 & 7.8 & 10.4 & 7.9 & 7.2 & 26.3 & 0.0 & 3.6 & 5.8 & 0.2 & 2.8 & 8.0 & 4.2 & 0.0 \\
\hline black cherry & 2.8 & 4.0 & 0.6 & 0.0 & 0.3 & 0.0 & 0.0 & 0.1 & 0.0 & 13.7 & 14.6 & 7.9 & 12.8 & 13.0 & 8.6 & 3.3 & 0.5 \\
\hline American beech & 4.0 & 5.9 & 2.3 & 0.0 & 3.3 & 7.0 & 8.8 & 5.3 & 7.3 & 0.0 & 0.0 & 0.0 & 0.4 & 0.1 & 8.1 & 9.2 & 19.2 \\
\hline striped maple & 1.2 & 3.1 & 13.3 & 0.0 & 1.4 & 6.0 & 7.3 & 3.6 & 0.0 & 0.0 & 1.1 & 1.9 & 1.2 & 1.2 & 0.0 & 0.0 & 1.2 \\
\hline devils-walkingstick & 0.7 & 3.1 & 5.6 & 2.9 & 5.1 & 7.9 & 6.5 & 5.5 & 0.0 & 0.0 & 0.0 & 0.0 & 0.0 & 0.0 & 0.0 & 0.0 & 0.0 \\
\hline white ash & 2.1 & 4.3 & 0.7 & 0.0 & 3.1 & 4.4 & 5.3 & 3.6 & 0.0 & 0.0 & 4.6 & 4.4 & 2.3 & 3.8 & 2.1 & 3.3 & 1.4 \\
\hline yellow birch & 0.0 & 0.0 & 0.0 & 0.0 & 0.4 & 0.0 & 1.4 & 0.6 & 0.0 & 0.0 & 0.2 & 3.9 & 0.0 & 0.5 & 9.7 & 1.6 & 0.4 \\
\hline fire cherry & 0.1 & 0.0 & 0.9 & 7.2 & 0.4 & 0.0 & 0.0 & 1.1 & 0.0 & 0.0 & 2.2 & 0.0 & 0.0 & 1.4 & 0.6 & 0.0 & 0.0 \\
\hline hickory & 0.2 & 1.0 & 0.0 & 0.0 & 0.4 & 0.0 & 0.5 & 0.3 & 0.0 & 0.0 & 2.6 & 1.3 & 2.8 & 2.4 & 1.0 & 6.4 & 0.4 \\
\hline northern red oak & 4.0 & 8.4 & 1.9 & 0.0 & 0.0 & 0.0 & 0.0 & 0.0 & 0.0 & 0.0 & 0.0 & 0.0 & 0.4 & 0.2 & 0.0 & 8.2 & 0.3 \\
\hline cucumber magnolia & 0.8 & 1.2 & 0.3 & 1.2 & 1.7 & 0.0 & 0.0 & 1.0 & 0.0 & 0.0 & 0.2 & 0.0 & 0.3 & 0.2 & 0.0 & 2.5 & 0.3 \\
\hline butternut & 0.0 & 0.0 & 0.0 & 0.0 & 0.0 & 0.0 & 0.0 & 0.0 & 0.0 & 0.0 & 0.0 & 3.9 & 0.0 & 0.4 & 0.0 & 0.1 & 0.0 \\
\hline red maple & 5.7 & 2.3 & 0.2 & 0.0 & 0.7 & 0.0 & 0.0 & 0.3 & 0.0 & 0.0 & 0.0 & 0.0 & 0.0 & 0.0 & 0.0 & 0.8 & 3.8 \\
\hline American hornbeam & 0.0 & 0.0 & 0.0 & 0.0 & 0.0 & 0.0 & 0.0 & 0.0 & 0.0 & 0.0 & 0.0 & 0.0 & 0.0 & 0.0 & 1.5 & 0.0 & 0.0 \\
\hline flowering dogwood & 0.3 & 0.5 & 0.0 & 0.0 & 0.0 & 0.0 & 0.6 & 0.2 & 0.0 & 0.0 & 0.0 & 0.0 & 0.0 & 0.0 & 0.0 & 0.0 & 0.0 \\
\hline staghorn sumac & 0.0 & 0.0 & 0.0 & 0.0 & 0.9 & 0.0 & 0.0 & 0.4 & 0.0 & 0.0 & 0.0 & 0.0 & 0.0 & 0.0 & 0.0 & 0.0 & 0.0 \\
\hline sassafras & 0.7 & 1.0 & 0.4 & 0.0 & 0.0 & 0.0 & 0.0 & 0.0 & 0.0 & 0.0 & 0.0 & 0.0 & 0.0 & 0.0 & 0.0 & 0.0 & 0.0 \\
\hline ironwood & 0.0 & 0.1 & 0.0 & 0.0 & 0.0 & 0.0 & 0.3 & 0.1 & 0.0 & 0.0 & 0.0 & 0.0 & 0.0 & 0.0 & 0.0 & 0.1 & 2.7 \\
\hline alternate-leaf dogwood & 0.0 & 0.1 & 0.1 & 0.0 & 0.0 & 0.0 & 0.0 & 0.0 & 0.0 & 0.0 & 0.0 & 0.0 & 0.0 & 0.0 & 0.0 & 0.0 & 0.0 \\
\hline chestnut oak & 0.0 & 0.1 & 0.0 & 0.0 & 0.0 & 0.0 & 0.0 & 0.0 & 0.0 & 0.0 & 0.0 & 0.0 & 0.0 & 0.0 & 0.0 & 0.6 & 0.3 \\
\hline white oak & 0.1 & 0.0 & 0.0 & 0.0 & 0.0 & 0.0 & 0.0 & 0.0 & 0.0 & 0.0 & 0.0 & 0.0 & 0.0 & 0.0 & 0.0 & 0.2 & 0.0 \\
\hline
\end{tabular}

${ }^{a} \mathrm{D}=$ dominant crown class; $\mathrm{CD}=$ co-dominant crown class; I = intermediate crown class; OT = overtopped crown class

${ }^{\mathrm{b}} \mathrm{OS}=$ total overstory (all crown classes); US = understory 
Table 3: Preharvest Relative Density

of Advanced Regeneration

\begin{tabular}{|lr|}
\hline species & $\begin{array}{c}\text { Advanced Regeneration } \\
\text { (\% trees/ha) }\end{array}$ \\
\hline sugar maple & 51.6 \\
American beech & 12.7 \\
black cherry & 8.7 \\
white ash & 4.7 \\
red elm & 3.4 \\
black birch & 2.9 \\
red maple & 2.7 \\
American basswood & 2.2 \\
hickory & 2.1 \\
cucumber magnolia & 2.0 \\
striped maple & 1.9 \\
downy serviceberry & 1.9 \\
northern red oak & 1.0 \\
chestnut oak & 0.7 \\
blackgum & 0.7 \\
ironwood & 0.3 \\
black locust & 0.3 \\
American chestnut & 0.3 \\
\hline
\end{tabular}


Table 4: Study Area Characteristics

Site Characteristics

Preharvest

Postharvest

\begin{tabular}{|c|c|c|c|c|c|c|c|c|c|c|c|c|c|c|c|c|}
\hline Stand & Age & $\begin{array}{l}\text { Size } \\
\text { (ha.) }\end{array}$ & Aspect & (\%) & $\overline{\mathrm{H}^{\prime}}$ & $\overline{\mathrm{S}}$ & $\bar{E}$ & $\begin{array}{c}\text { Density } \\
\geq 12.7 \mathrm{~cm} \\
\text { (trees } / \mathrm{ha} \text { ) }\end{array}$ & $\begin{array}{c}\text { Basal Area } \\
\geq 12.7 \mathrm{~cm} \\
\left(\mathrm{~m}^{2} / \mathrm{ha}\right)\end{array}$ & $\mathrm{H}^{\prime}$ & $\overline{\mathrm{S}}$ & $\bar{E}$ & $\begin{array}{c}\text { Density } \\
\text { All Trees } \\
\text { (trees/ha) }\end{array}$ & SE & $\begin{array}{c}\text { Basal Area } \\
\text { All Trees } \\
\left(\mathrm{m}^{2} / \mathrm{ha}\right)\end{array}$ & SE \\
\hline 1 & 2 & 2.09 & 355 & 30 & 1.890 & 15 & 0.698 & 285 & 29.03 & 1.744 & 13 & 0.680 & 38,575 & 7,079 & 0.00 & 0.00 \\
\hline 2 & 3 & 2.06 & 330 & 5 & 2.401 & 21 & 0.789 & 320 & 32.23 & 2.159 & 21 & 0.709 & 53,550 & 6,632 & 0.34 & 0.23 \\
\hline 4 & 6 & 0.61 & 25 & 60 & 1.681 & 8 & 0.809 & 236 & 24.66 & 1.357 & 8 & 0.691 & 16,391 & 5,085 & 0.41 & 0.31 \\
\hline 5 & 6 & 0.40 & 295 & 60 & 2.251 & 14 & 0.853 & 267 & 28.57 & 1.655 & 12 & 0.666 & 98,840 & 10,008 & 0.00 & 0.00 \\
\hline 6 & 12 & 1.86 & 340 & 30 & 1.919 & 14 & 0.727 & 194 & 25.53 & 1.577 & 12 & 0.635 & 9,266 & 2,392 & 14.14 & 1.48 \\
\hline 9 & 16 & 0.32 & 290 & 60 & 2.145 & 13 & 0.836 & 284 & 28.07 & 2.016 & 12 & 0.811 & 8,392 & 2,528 & 13.80 & 2.39 \\
\hline 10 & 22 & 2.08 & 350 & 30 & $n / a^{a}$ & $\mathrm{n} / \mathrm{a}$ & $n / a$ & $\mathrm{n} / \mathrm{a}$ & $\mathrm{n} / \mathrm{a}$ & 2.026 & 13 & 0.790 & 3,253 & 556 & 17.97 & 1.65 \\
\hline 11 & 23 & 1.50 & 325 & 10 & 2.087 & 16 & 0.753 & 245 & 20.75 & 1.667 & 13 & 0.650 & 4,189 & 763 & 35.83 & 1.61 \\
\hline 12 & 26 & 0.73 & 60 & 55 & 2.074 & 15 & 0.766 & 281 & 30.34 & 2.006 & 15 & 0.741 & 23,288 & 7,863 & 20.80 & 0.88 \\
\hline 13 & 26 & 0.32 & 35 & 50 & 1.682 & 7 & 0.864 & 380 & 40.50 & 1.613 & 10 & 0.701 & 3,690 & 2,330 & 23.60 & 3.95 \\
\hline
\end{tabular}

$\mathrm{H}^{\prime}$ = Shannon-Weaver Diversity Index; $\mathrm{S}=$ total number of species present on each stand; $\mathrm{E}=$ Pielou's evenness index $\mathrm{SE}=$ Standard Error

${ }^{a}$ Preharvest data not available for stand 10 
Table 5: Postharvest Species Composition, Relative Trees per Hectare ( $r$ t/ha), Relative Basal Area per Hectare ( $\mathrm{rba} / \mathrm{ha}$ ), and Relative Importance Value (riv)

\begin{tabular}{|c|c|c|c|c|c|c|c|c|c|c|c|c|c|c|c|c|c|c|c|c|c|}
\hline \multirow[b]{3}{*}{ Species } & \multicolumn{21}{|c|}{ Stands } \\
\hline & \multicolumn{3}{|c|}{ All Stands } & \multicolumn{3}{|c|}{$1^{\mathrm{a}}$} & \multicolumn{3}{|c|}{2} & \multicolumn{3}{|c|}{3} & \multicolumn{3}{|c|}{4} & \multicolumn{3}{|c|}{$5^{\mathrm{a}}$} & \multicolumn{3}{|c|}{6} \\
\hline & $\mathrm{rt}$ /ha & $\mathrm{rba} / \mathrm{ha}$ & riv & $\mathrm{rt}$ tha & $\mathrm{rba} / \mathrm{ha}$ & riv & $\mathrm{rt}$ tha & $\mathrm{rba} / \mathrm{ha}$ & riv & $\mathrm{rt}$ /ha & $\mathrm{rba} / \mathrm{ha}$ & riv & $r$ t/ha & $\mathrm{rba} / \mathrm{ha}$ & riv & $r$ t/ha & $\mathrm{rba} / \mathrm{ha}$ & riv & $\mathrm{rt} / \mathrm{ha}$ & $\mathrm{rba} / \mathrm{ha}$ & riv \\
\hline yellow poplar & 18.3 & 37.2 & 26.4 & 26.7 & $\mathrm{n} / \mathrm{a}$ & 26.7 & 28.1 & 0.0 & 14.1 & 24.3 & 6.1 & 15.2 & 41.1 & 77.9 & 59.5 & 12.3 & $\mathrm{n} / \mathrm{a}$ & 12.3 & 35.0 & 45.4 & 40.2 \\
\hline sugar maple & 29.6 & 8.1 & 20.8 & 42.3 & $\mathrm{n} / \mathrm{a}$ & 42.3 & 12.5 & 0.0 & 6.3 & 26.6 & 23.3 & 25.0 & 17.5 & 6.2 & 11.8 & 25.7 & $\mathrm{n} / \mathrm{a}$ & 25.7 & 2.1 & 0.5 & 1.3 \\
\hline black birch & 8.5 & 5.6 & 8.2 & 0.0 & $\mathrm{n} / \mathrm{a}$ & 0.0 & 15.2 & 6.3 & 10.8 & 12.6 & 14.3 & 13.4 & 9.7 & 0.0 & 4.8 & 41.1 & $\mathrm{n} / \mathrm{a}$ & 41.1 & 3.1 & 3.2 & 3.2 \\
\hline American basswood & 3.4 & 13.4 & 7.6 & 6.4 & $\mathrm{n} / \mathrm{a}$ & 6.4 & 0.4 & 59.7 & 30.1 & 0.0 & 0.0 & 0.0 & 0.0 & 0.0 & 0.0 & 0.0 & $\mathrm{n} / \mathrm{a}$ & 0.0 & 10.6 & 28.0 & 19.3 \\
\hline white ash & 10.5 & 2.4 & 6.5 & 5.3 & $\mathrm{n} / \mathrm{a}$ & 5.3 & 5.5 & 0.0 & 2.8 & 0.6 & 0.0 & 0.3 & 9.7 & 0.0 & 4.8 & 0.7 & $\mathrm{n} / \mathrm{a}$ & 0.7 & 41.8 & 7.0 & 24.4 \\
\hline red elm & 4.6 & 5.2 & 4.5 & 0.0 & $\mathrm{n} / \mathrm{a}$ & 0.0 & 0.0 & 0.0 & 0.0 & 0.0 & 0.0 & 0.0 & 7.7 & 15.9 & 11.8 & 0.0 & $\mathrm{n} / \mathrm{a}$ & 0.0 & 0.4 & 1.3 & 0.9 \\
\hline striped maple & 4.7 & 4.4 & 4.5 & 2.5 & $\mathrm{n} / \mathrm{a}$ & 2.5 & 1.3 & 0.0 & 0.7 & 9.9 & 37.2 & 23.5 & 0.0 & 0.0 & 0.0 & 3.6 & $\mathrm{n} / \mathrm{a}$ & 3.6 & 0.0 & 0.0 & 0.0 \\
\hline black locust & 1.5 & 8.2 & 4.3 & 3.2 & $\mathrm{n} / \mathrm{a}$ & 3.2 & 0.4 & 0.0 & 0.2 & 0.8 & 12.3 & 6.6 & 0.0 & 0.0 & 0.0 & 0.0 & $\mathrm{n} / \mathrm{a}$ & 0.0 & 2.9 & 13.0 & 7.9 \\
\hline black cherry & 3.2 & 4.7 & 3.7 & 1.1 & $\mathrm{n} / \mathrm{a}$ & 1.1 & 6.6 & 0.0 & 3.3 & 2.2 & 0.0 & 1.1 & 7.2 & 0.0 & 3.6 & 1.9 & $\mathrm{n} / \mathrm{a}$ & 1.9 & 1.5 & 0.0 & 0.7 \\
\hline American beech & 3.4 & 2.2 & 2.9 & 4.6 & $\mathrm{n} / \mathrm{a}$ & 4.6 & 6.8 & 5.1 & 6.0 & 7.1 & 3.2 & 5.2 & 7.2 & 0.0 & 3.6 & 1.5 & $\mathrm{n} / \mathrm{a}$ & 1.5 & 0.3 & 0.2 & 0.3 \\
\hline devils-walkingstick & 1.7 & 4.4 & 2.8 & 2.9 & $\mathrm{n} / \mathrm{a}$ & 2.9 & 4.6 & 28.8 & 16.7 & 3.8 & 1.4 & 2.6 & 0.0 & 0.0 & 0.0 & 1.1 & $\mathrm{n} / \mathrm{a}$ & 1.1 & 0.1 & 0.0 & 0.1 \\
\hline northern red oak & 4.8 & 0.0 & 2.8 & 0.4 & $\mathrm{n} / \mathrm{a}$ & 0.4 & 5.1 & 0.0 & 2.5 & 2.2 & 0.0 & 1.1 & 0.0 & 0.0 & 0.0 & 9.8 & $\mathrm{n} / \mathrm{a}$ & 9.8 & 0.0 & 0.0 & 0.0 \\
\hline red maple & 1.5 & 0.1 & 0.9 & 3.2 & $\mathrm{n} / \mathrm{a}$ & 3.2 & 5.7 & 0.0 & 2.9 & 5.9 & 0.0 & 3.0 & 0.0 & 0.0 & 0.0 & 1.1 & $\mathrm{n} / \mathrm{a}$ & 1.1 & 0.0 & 0.0 & 0.0 \\
\hline fire cherry & 0.3 & 1.8 & 0.9 & 0.0 & $\mathrm{n} / \mathrm{a}$ & 0.0 & 0.2 & 0.0 & 0.1 & 1.2 & 2.1 & 1.6 & 0.0 & 0.0 & 0.0 & 0.0 & $\mathrm{n} / \mathrm{a}$ & 0.0 & 0.0 & 0.0 & 0.0 \\
\hline hickory & 1.2 & 0.6 & 0.9 & 0.7 & $\mathrm{n} / \mathrm{a}$ & 0.7 & 0.2 & 0.0 & 0.1 & 0.6 & 0.0 & 0.3 & 0.0 & 0.0 & 0.0 & 0.7 & $\mathrm{n} / \mathrm{a}$ & 0.7 & 0.3 & 0.8 & 0.5 \\
\hline cucumber magnolia & 1.1 & 0.6 & 0.9 & 0.7 & $\mathrm{n} / \mathrm{a}$ & 0.7 & 1.3 & 0.0 & 0.7 & 1.6 & 0.0 & 0.8 & 0.0 & 0.0 & 0.0 & 0.7 & $\mathrm{n} / \mathrm{a}$ & 0.7 & 0.0 & 0.0 & 0.0 \\
\hline yellow birch & 0.8 & 0.4 & 0.6 & 0.0 & $\mathrm{n} / \mathrm{a}$ & 0.0 & 0.0 & 0.0 & 0.0 & 0.0 & 0.0 & 0.0 & 0.0 & 0.0 & 0.0 & 0.0 & $\mathrm{n} / \mathrm{a}$ & 0.0 & 1.9 & 0.5 & 1.2 \\
\hline flowering dogwood & 0.5 & 0.0 & 0.3 & 0.0 & $\mathrm{n} / \mathrm{a}$ & 0.0 & 1.3 & 0.0 & 0.7 & 0.0 & 0.0 & 0.0 & 0.0 & 0.0 & 0.0 & 0.0 & $\mathrm{n} / \mathrm{a}$ & 0.0 & 0.0 & 0.0 & 0.0 \\
\hline staghorn sumac & 0.1 & 0.3 & 0.2 & 0.0 & $\mathrm{n} / \mathrm{a}$ & 0.0 & 0.0 & 0.0 & 0.0 & 0.0 & 0.0 & 0.0 & 0.0 & 0.0 & 0.0 & 0.0 & $\mathrm{n} / \mathrm{a}$ & 0.0 & 0.0 & 0.0 & 0.0 \\
\hline sassafras & 0.3 & 0.0 & 0.1 & 0.0 & $\mathrm{n} / \mathrm{a}$ & 0.0 & 3.3 & 0.0 & 1.7 & 0.6 & 0.0 & 0.3 & 0.0 & 0.0 & 0.0 & 0.0 & $\mathrm{n} / \mathrm{a}$ & 0.0 & 0.0 & 0.0 & 0.0 \\
\hline butternut & 0.0 & 0.2 & 0.1 & 0.0 & $\mathrm{n} / \mathrm{a}$ & 0.0 & 0.0 & 0.0 & 0.0 & 0.0 & 0.0 & 0.0 & 0.0 & 0.0 & 0.0 & 0.0 & $\mathrm{n} / \mathrm{a}$ & 0.0 & 0.0 & 0.0 & 0.0 \\
\hline ironwood & 0.0 & 0.0 & 0.0 & 0.0 & $\mathrm{n} / \mathrm{a}$ & 0.0 & 0.2 & 0.0 & 0.1 & 0.0 & 0.0 & 0.0 & 0.0 & 0.0 & 0.0 & 0.0 & $\mathrm{n} / \mathrm{a}$ & 0.0 & 0.0 & 0.0 & 0.0 \\
\hline American hornbeam & 0.0 & 0.0 & 0.0 & 0.0 & $\mathrm{n} / \mathrm{a}$ & 0.0 & 0.0 & 0.0 & 0.0 & 0.0 & 0.0 & 0.0 & 0.0 & 0.0 & 0.0 & 0.0 & $\mathrm{n} / \mathrm{a}$ & 0.0 & 0.0 & 0.0 & 0.0 \\
\hline alternate-leaf dogwood & 0.0 & 0.0 & 0.0 & 0.0 & $\mathrm{n} / \mathrm{a}$ & 0.0 & 0.4 & 0.0 & 0.2 & 0.0 & 0.0 & 0.0 & 0.0 & 0.0 & 0.0 & 0.0 & $\mathrm{n} / \mathrm{a}$ & 0.0 & 0.0 & 0.0 & 0.0 \\
\hline chestnut oak & 0.0 & 0.0 & 0.0 & 0.0 & $\mathrm{n} / \mathrm{a}$ & 0.0 & 0.2 & 0.0 & 0.1 & 0.0 & 0.0 & 0.0 & 0.0 & 0.0 & 0.0 & 0.0 & $\mathrm{n} / \mathrm{a}$ & 0.0 & 0.0 & 0.0 & 0.0 \\
\hline white oak & 0.0 & 0.0 & 0.0 & 0.0 & $\mathrm{n} / \mathrm{a}$ & 0.0 & 0.2 & 0.0 & 0.1 & 0.0 & 0.0 & 0.0 & 0.0 & 0.0 & 0.0 & 0.0 & $\mathrm{n} / \mathrm{a}$ & 0.0 & 0.0 & 0.0 & 0.0 \\
\hline
\end{tabular}

${ }^{\text {a }}$ Stands do not contain any stems $\geq 2.54 \mathrm{~cm} \mathrm{dbh}$ 
Table 5: Postharvest Species Composition, Relative Trees per Hectare ( $r$ t/ha), Relative Basal Area per Hectare ( $\mathrm{rba} / \mathrm{ha}$ ), and Relative Importance Value (riv)

\begin{tabular}{|c|c|c|c|c|c|c|c|c|c|c|c|c|c|c|c|c|c|c|c|c|c|}
\hline \multirow[b]{3}{*}{ Species } & \multicolumn{21}{|c|}{ Stands } \\
\hline & \multicolumn{3}{|c|}{7} & \multicolumn{3}{|c|}{8} & \multicolumn{3}{|c|}{9} & \multicolumn{3}{|c|}{10} & \multicolumn{3}{|c|}{11} & \multicolumn{3}{|c|}{12} & \multicolumn{3}{|c|}{13} \\
\hline & $\mathrm{rt} / \mathrm{ha}$ & $\mathrm{rba} / \mathrm{ha}$ & $\mathrm{riv}$ & $\mathrm{rt} / \mathrm{ha}$ & $\mathrm{rba} / \mathrm{ha}$ & $\mathrm{riv}$ & $\mathrm{rt} / \mathrm{ha}$ & $\mathrm{rba} / \mathrm{ha}$ & $r$ iv & $\mathrm{rt} / \mathrm{ha}$ & $\mathrm{rba} / \mathrm{ha}$ & riv & $\mathrm{rt} / \mathrm{ha}$ & $\mathrm{rba} / \mathrm{ha}$ & $\mathrm{riv}$ & $\mathrm{rt} / \mathrm{ha}$ & $\mathrm{rba} / \mathrm{ha}$ & riv & $\mathrm{rt} / \mathrm{ha}$ & $\mathrm{rba} / \mathrm{ha}$ & $\mathrm{riv}$ \\
\hline yellow poplar & 9.2 & 20.3 & 14.7 & 5.5 & 24.3 & 14.9 & 8.2 & 33.7 & 21.0 & 6.5 & 31.5 & 19.0 & 26.7 & 60.1 & 43.4 & 3.3 & 31.1 & 17.2 & 11.6 & 79.0 & 45.3 \\
\hline sugar maple & 17.0 & 3.0 & 10.0 & 64.0 & 24.2 & 44.1 & 37.7 & 8.0 & 22.9 & 51.5 & 7.5 & 29.5 & 29.0 & 2.6 & 15.8 & 56.2 & 13.5 & 34.8 & 2.2 & 0.4 & 1.3 \\
\hline black birch & 14.4 & 11.8 & 13.1 & 1.1 & 1.0 & 1.1 & 6.5 & 7.8 & 7.1 & 6.4 & 6.6 & 6.5 & 0.0 & 0.0 & 0.0 & 0.4 & 10.3 & 5.4 & 0.4 & 0.9 & 0.7 \\
\hline American basswood & 5.1 & 9.0 & 7.0 & 0.3 & 1.6 & 0.9 & 1.1 & 7.1 & 4.1 & 14.4 & 22.1 & 18.3 & 2.1 & 1.0 & 1.6 & 1.2 & 16.1 & 8.7 & 2.7 & 2.8 & 2.7 \\
\hline white ash & 19.0 & 1.3 & 10.1 & 3.4 & 2.5 & 3.0 & 0.0 & 0.0 & 0.0 & 4.2 & 7.5 & 5.9 & 1.6 & 1.4 & 1.5 & 0.1 & 4.4 & 2.3 & 45.1 & 2.5 & 23.8 \\
\hline red elm & 0.0 & 0.0 & 0.0 & 16.6 & 21.3 & 18.9 & 26.5 & 2.9 & 14.7 & 1.9 & 8.9 & 5.4 & 3.0 & 1.1 & 2.0 & 0.0 & 0.0 & 0.0 & 3.6 & 5.8 & 4.7 \\
\hline striped maple & 8.0 & 7.6 & 7.8 & 1.5 & 1.1 & 1.3 & 0.0 & 0.0 & 0.0 & 6.3 & 0.8 & 3.5 & 0.0 & 0.0 & 0.0 & 28.5 & 1.7 & 15.1 & 0.0 & 0.0 & 0.0 \\
\hline black locust & 3.6 & 18.7 & 11.1 & 3.9 & 20.5 & 12.2 & 3.2 & 18.2 & 10.7 & 0.2 & 0.9 & 0.5 & 0.7 & 3.5 & 2.1 & 0.1 & 3.0 & 1.5 & 0.0 & 0.0 & 0.0 \\
\hline black cherry & 4.8 & 1.1 & 2.9 & 0.0 & 0.0 & 0.0 & 0.0 & 0.0 & 0.0 & 2.3 & 8.1 & 5.2 & 13.2 & 30.0 & 21.6 & 0.5 & 12.1 & 6.3 & 0.0 & 0.0 & 0.0 \\
\hline American beech & 0.8 & 0.7 & 0.7 & 0.0 & 0.0 & 0.0 & 14.1 & 13.7 & 13.9 & 0.0 & 0.0 & 0.0 & 0.5 & 0.0 & 0.2 & 1.0 & 1.7 & 1.3 & 0.0 & 0.0 & 0.0 \\
\hline devils-walkingstick & 8.0 & 16.6 & 12.3 & 0.6 & 0.0 & 0.3 & 0.6 & 1.3 & 1.0 & 0.0 & 0.0 & 0.0 & 0.0 & 0.0 & 0.0 & 0.0 & 0.0 & 0.0 & 0.0 & 0.0 & 0.0 \\
\hline northern red oak & 0.0 & 0.0 & 0.0 & 0.0 & 0.0 & 0.0 & 0.0 & 0.0 & 0.0 & 5.2 & 0.1 & 2.6 & 13.6 & 0.0 & 6.8 & 3.5 & 0.0 & 1.8 & 22.3 & 0.0 & 11.2 \\
\hline red maple & 2.6 & 0.0 & 1.3 & 0.4 & 1.1 & 0.8 & 0.0 & 0.0 & 0.0 & 0.0 & 0.0 & 0.0 & 0.0 & 0.0 & 0.0 & 0.0 & 0.0 & 0.0 & 0.0 & 0.0 & 0.0 \\
\hline fire cherry & 0.8 & 6.1 & 3.5 & 0.1 & 0.6 & 0.4 & 0.1 & 1.4 & 0.8 & 0.6 & 5.3 & 3.0 & 0.5 & 0.1 & 0.3 & 0.1 & 4.6 & 2.3 & 0.0 & 0.0 & 0.0 \\
\hline hickory & 2.6 & 0.0 & 1.3 & 0.0 & 0.5 & 0.2 & 0.6 & 0.2 & 0.4 & 0.5 & 0.2 & 0.3 & 4.5 & 0.0 & 2.3 & 0.1 & 0.2 & 0.2 & 4.5 & 5.2 & 4.8 \\
\hline cucumber magnolia & 2.6 & 0.0 & 1.3 & 2.0 & 0.4 & 1.2 & 0.8 & 5.3 & 3.1 & 0.2 & 0.6 & 0.4 & 0.1 & 0.1 & 0.1 & 4.7 & 0.0 & 2.4 & 0.0 & 0.0 & 0.0 \\
\hline yellow birch & 1.2 & 1.7 & 1.4 & 0.0 & 0.0 & 0.0 & 0.0 & 0.0 & 0.0 & 0.0 & 0.0 & 0.0 & 0.0 & 0.0 & 0.0 & 0.1 & 0.9 & 0.5 & 7.1 & 1.4 & 4.3 \\
\hline flowering dogwood & 0.0 & 0.0 & 0.0 & 0.0 & 0.0 & 0.0 & 0.6 & 0.4 & 0.5 & 0.0 & 0.0 & 0.0 & 4.5 & 0.0 & 2.3 & 0.0 & 0.0 & 0.0 & 0.0 & 0.0 & 0.0 \\
\hline staghorn sumac & 0.8 & 2.1 & 1.4 & 0.4 & 0.9 & 0.7 & 0.0 & 0.0 & 0.0 & 0.0 & 0.0 & 0.0 & 0.0 & 0.0 & 0.0 & 0.0 & 0.0 & 0.0 & 0.0 & 0.0 & 0.0 \\
\hline sassafras & 0.0 & 0.0 & 0.0 & 0.0 & 0.0 & 0.0 & 0.0 & 0.0 & 0.0 & 0.0 & 0.0 & 0.0 & 0.0 & 0.0 & 0.0 & 0.0 & 0.0 & 0.0 & 0.0 & 0.0 & 0.0 \\
\hline butternut & 0.0 & 0.0 & 0.0 & 0.0 & 0.0 & 0.0 & 0.0 & 0.0 & 0.0 & 0.0 & 0.0 & 0.0 & 0.0 & 0.0 & 0.0 & 0.0 & 0.0 & 0.0 & 0.4 & 2.0 & 1.2 \\
\hline ironwood & 0.0 & 0.0 & 0.0 & 0.2 & 0.2 & 0.2 & 0.0 & 0.0 & 0.0 & 0.0 & 0.0 & 0.0 & 0.0 & 0.0 & 0.0 & 0.0 & 0.0 & 0.0 & 0.0 & 0.0 & 0.0 \\
\hline American hornbeam & 0.0 & 0.0 & 0.0 & 0.0 & 0.0 & 0.0 & 0.0 & 0.0 & 0.0 & 0.0 & 0.0 & 0.0 & 0.0 & 0.0 & 0.0 & 0.1 & 0.4 & 0.3 & 0.0 & 0.0 & 0.0 \\
\hline alternate-leaf dogwood & 0.0 & 0.0 & 0.0 & 0.0 & 0.0 & 0.0 & 0.0 & 0.0 & 0.0 & 0.0 & 0.0 & 0.0 & 0.0 & 0.0 & 0.0 & 0.0 & 0.0 & 0.0 & 0.0 & 0.0 & 0.0 \\
\hline chestnut oak & 0.0 & 0.0 & 0.0 & 0.0 & 0.0 & 0.0 & 0.0 & 0.0 & 0.0 & 0.0 & 0.0 & 0.0 & 0.0 & 0.0 & 0.0 & 0.0 & 0.0 & 0.0 & 0.0 & 0.0 & 0.0 \\
\hline white oak & 0.0 & 0.0 & 0.0 & 0.0 & 0.0 & 0.0 & 0.0 & 0.0 & 0.0 & 0.0 & 0.0 & 0.0 & 0.0 & 0.0 & 0.0 & 0.0 & 0.0 & 0.0 & 0.0 & 0.0 & 0.0 \\
\hline
\end{tabular}


Table 6: Postharvest Relative Importance Value (riv), Relative Trees per Hectare ( $r$ tha), and Relative Basal Area per Hectare ( $\mathrm{r}$ ba/ha) for each Age Class

\begin{tabular}{|lrrr|}
\hline \multicolumn{4}{|c|}{ 2-6 Year Old Stands } \\
& riv & r tha & r ba/ha \\
\hline Species & 23.5 & 22.2 & 24.8 \\
yellow poplar & 19.3 & 25.5 & 13.2 \\
sugar maple & 15.6 & 22.8 & 8.5 \\
black birch & 11.0 & 3.7 & 18.3 \\
striped maple & 7.4 & 1.1 & 13.6 \\
American basswood & 4.9 & 2.5 & 7.3 \\
devils-walkingstick & 3.4 & 4.1 & 2.7 \\
American beech & 3.4 & 0.8 & 6.0 \\
black locust & 2.8 & 5.5 & 0.0 \\
northern red oak & 2.3 & 0.2 & 4.5 \\
red elm & 1.6 & 3.1 & 0.0 \\
red maple & 1.4 & 2.9 & 0.0 \\
black cherry & 1.4 & 2.7 & 0.0 \\
white ash & 0.6 & 0.2 & 1.0 \\
fire cherry & 0.4 & 0.8 & 0.0 \\
cucumber magnolia & 0.4 & 0.8 & 0.0 \\
sassafras & 0.2 & 0.4 & 0.0 \\
hickory & 0.1 & 0.3 & 0.0 \\
flowering dogwood & 0.0 & 0.1 & 0.0 \\
alternate-leaf dogwood & 0.0 & 0.0 & 0.0 \\
chestnut oak & 0.0 & 0.0 & 0.0 \\
ironwood & 0.0 & 0.0 & 0.0 \\
white oak & 0.0 & 0.0 & 0.0 \\
butternut & 0.0 & 0.0 & 0.0 \\
American hornbeam & 0.0 & 0.0 & 0.0 \\
staghorn sumac & 0.0 & 0.0 & 0.0 \\
yellow birch & & &
\end{tabular}

\begin{tabular}{|lrrr|}
\hline \multicolumn{4}{|c|}{ 12-16 Year Old Stands } \\
Species & riv & r t $/$ ha & r ba/ha \\
\hline yellow poplar & 22.2 & 13.8 & 30.6 \\
sugar maple & 20.5 & 30.8 & 10.1 \\
black locust & 10.8 & 3.3 & 18.2 \\
white ash & 9.6 & 16.6 & 2.6 \\
red elm & 8.7 & 9.8 & 7.7 \\
American basswood & 7.4 & 4.3 & 10.6 \\
black birch & 6.2 & 6.9 & 5.5 \\
devils-walkingstick & 3.5 & 2.7 & 4.3 \\
American beech & 3.1 & 3.1 & 3.2 \\
striped maple & 2.4 & 2.8 & 2.0 \\
cucumber magnolia & 1.4 & 1.4 & 1.4 \\
fire cherry & 1.0 & 0.1 & 1.9 \\
black cherry & 0.9 & 1.8 & 0.1 \\
red maple & 0.6 & 0.8 & 0.4 \\
hickory & 0.5 & 0.9 & 0.2 \\
yellow birch & 0.5 & 0.6 & 0.4 \\
staghorn sumac & 0.4 & 0.1 & 0.6 \\
flowering dogwood & 0.1 & 0.1 & 0.1 \\
ironwood & 0.1 & 0.1 & 0.0 \\
alternate-leaf dogwood & 0.0 & 0.0 & 0.0 \\
butternut & 0.0 & 0.0 & 0.0 \\
chestnut oak & 0.0 & 0.0 & 0.0 \\
American hornbeam & 0.0 & 0.0 & 0.0 \\
northern red oak & 0.0 & 0.0 & 0.0 \\
sassafras & 0.0 & 0.0 & 0.0 \\
white oak & 0.0 & 0.0 & 0.0 \\
\hline
\end{tabular}

\begin{tabular}{|lrrr|}
\hline \multicolumn{4}{|c|}{ 22-26 Year Old Stands } \\
& riv & r t tha & r ba/ha \\
\hline Species & 29.9 & 7.3 & 52.5 \\
yellow poplar & 26.0 & 46.7 & 5.3 \\
sugar maple & 10.2 & 19.9 & 0.5 \\
striped maple & 8.6 & 2.1 & 15.2 \\
black cherry & 5.7 & 2.7 & 8.6 \\
American basswood & 4.5 & 5.5 & 3.5 \\
white ash & 3.5 & 6.9 & 0.0 \\
northern red oak & 2.3 & 0.9 & 3.6 \\
black birch & 2.2 & 0.9 & 3.4 \\
red elm & 1.7 & 3.2 & 0.2 \\
cucumber magnolia & 1.2 & 1.2 & 1.3 \\
hickory & 1.1 & 0.2 & 2.1 \\
black locust & 1.1 & 0.2 & 2.0 \\
fire cherry & 0.9 & 0.8 & 1.0 \\
yellow birch & 0.5 & 0.7 & 0.4 \\
American beech & 0.3 & 0.6 & 0.0 \\
flowering dogwood & 0.3 & 0.0 & 0.5 \\
butternut & 0.1 & 0.1 & 0.1 \\
American hornbeam & 0.0 & 0.0 & 0.0 \\
alternate-leaf dogwood & 0.0 & 0.0 & 0.0 \\
chestnut oak & 0.0 \\
devils-walkingstick & 0.0 & 0.0 & 0.0 \\
ironwood & 0.0 & 0.0 & 0.0 \\
red maple & 0.0 & 0.0 & 0.0 \\
sassafras & 0.0 & 0.0 & 0.0 \\
staghorn sumac & 0.0 & 0.0 & 0.0 \\
white oak & 0.0 & 0.0 & 0.0 \\
\hline
\end{tabular}


Table 7: Relative Basal Area per Hectare for each Age Class, Crown Class ${ }^{a}$, and Canopy Strata ${ }^{b}$

\begin{tabular}{|c|c|c|c|c|c|c|c|c|c|c|c|c|c|c|c|}
\hline \multirow[b]{2}{*}{ Species } & \multirow{2}{*}{$\begin{array}{l}\text { 2-6 Years } \\
\geq 2.54 \mathrm{~cm} \mathrm{dbh}\end{array}$} & \multicolumn{6}{|c|}{ 12-16 Years } & \multicolumn{6}{|c|}{ 22-26 Years } & \multicolumn{2}{|c|}{ Pre-Harvest } \\
\hline & & $\mathrm{D}$ & $C D$ & $\mathrm{I}$ & OT & OS & US & $\mathrm{D}$ & $\mathrm{CD}$ & $\mathrm{I}$ & OT & OS & US & os & $U^{a}$ \\
\hline yellow poplar & 24.8 & 35.4 & 32.6 & 28.8 & 19.8 & 30.6 & 0.0 & 47.9 & 58.6 & 40.6 & 35.9 & 53.9 & 24.7 & 21.2 & $\mathrm{n} / \mathrm{a}$ \\
\hline sugar maple & 13.2 & 0.0 & 8.2 & 14.4 & 24.0 & 10.0 & 54.6 & 0.0 & 1.1 & 2.3 & 23.4 & 4.0 & 31.1 & 19.9 & $\mathrm{n} / \mathrm{a}$ \\
\hline black locust & 6.0 & 46.3 & 16.3 & 4.2 & 7.0 & 18.2 & 0.0 & 34.4 & 2.1 & 0.0 & 0.0 & 2.2 & 0.0 & 2.3 & $\mathrm{n} / \mathrm{a}$ \\
\hline American basswood & 13.6 & 2.8 & 15.3 & 4.7 & 7.1 & 10.6 & 14.7 & 0.0 & 6.8 & 18.2 & 14.9 & 8.7 & 5.5 & 14.6 & $\mathrm{n} / \mathrm{a}$ \\
\hline red elm & 4.5 & 0.0 & 8.1 & 13.2 & 9.3 & 5.5 & 24.0 & 0.0 & 3.4 & 6.5 & 0.3 & 3.8 & 7.7 & 1.5 & $\mathrm{n} / \mathrm{a}$ \\
\hline black cherry & 0.0 & 0.0 & 0.2 & 0.0 & 0.0 & 7.6 & 0.0 & 17.7 & 15.9 & 10.3 & 15.9 & 3.2 & 10.1 & 4.3 & $\mathrm{n} / \mathrm{a}$ \\
\hline black birch & 8.5 & 2.2 & 5.1 & 12.2 & 4.9 & 0.1 & 0.0 & 0.0 & 3.6 & 6.5 & 3.6 & 15.4 & 0.0 & 3.6 & $\mathrm{n} / \mathrm{a}$ \\
\hline striped maple & 18.3 & 0.0 & 0.4 & 6.1 & 6.6 & 3.1 & 0.0 & 0.0 & 0.4 & 2.2 & 0.5 & 0.1 & 0.0 & 9.4 & $\mathrm{n} / \mathrm{a}$ \\
\hline American beech & 2.7 & 0.0 & 2.3 & 6.5 & 6.5 & 2.1 & 6.7 & 0.0 & 0.0 & 0.0 & 0.6 & 0.5 & 6.2 & 0.0 & $\mathrm{n} / \mathrm{a}$ \\
\hline devils-walkingstick & 7.3 & 2.4 & 3.8 & 6.0 & 7.2 & 4.4 & 0.0 & 0.0 & 0.0 & 0.0 & 0.0 & 0.0 & 0.0 & 0.0 & $\mathrm{n} / \mathrm{a}$ \\
\hline white ash & 0.0 & 0.0 & 2.4 & 3.8 & 5.0 & 2.6 & 0.0 & 0.0 & 3.9 & 2.8 & 2.3 & 3.5 & 2.6 & 3.3 & $\mathrm{n} / \mathrm{a}$ \\
\hline yellow birch & 0.0 & 0.0 & 0.3 & 0.0 & 1.3 & 0.4 & 0.0 & 0.0 & 0.2 & 4.8 & 0.0 & 0.6 & 9.1 & 1.2 & $\mathrm{n} / \mathrm{a}$ \\
\hline fire cherry & 1.0 & 9.3 & 0.6 & 0.0 & 0.0 & 1.9 & 0.0 & 0.0 & 2.7 & 0.0 & 0.0 & 2.1 & 0.5 & 0.0 & $\mathrm{n} / \mathrm{a}$ \\
\hline butternut & 0.0 & 0.0 & 0.0 & 0.0 & 0.0 & 0.2 & 0.0 & 0.0 & 0.0 & 5.4 & 0.0 & 1.3 & 0.0 & 6.1 & $\mathrm{n} / \mathrm{a}$ \\
\hline hickory & 0.0 & 0.0 & 0.3 & 0.0 & 0.3 & 0.0 & 0.0 & 0.0 & 1.4 & 0.3 & 2.0 & 0.0 & 0.8 & 9.2 & $\mathrm{n} / \mathrm{a}$ \\
\hline cucumber magnolia & 0.0 & 1.5 & 2.2 & 0.0 & 0.0 & 1.4 & 0.0 & 0.0 & 0.1 & 0.0 & 0.4 & 0.2 & 0.0 & 1.9 & $\mathrm{n} / \mathrm{a}$ \\
\hline American hornbeam & 0.0 & 0.0 & 0.0 & 0.0 & 0.0 & 0.0 & 0.0 & 0.0 & 0.0 & 0.0 & 0.0 & 0.5 & 1.9 & 0.1 & $\mathrm{n} / \mathrm{a}$ \\
\hline staghorn sumac & 0.0 & 0.0 & 1.2 & 0.0 & 0.0 & 0.4 & 0.0 & 0.0 & 0.0 & 0.0 & 0.0 & 0.0 & 0.0 & 0.7 & $\mathrm{n} / \mathrm{a}$ \\
\hline red maple & 0.0 & 0.0 & 0.7 & 0.0 & 0.0 & 0.0 & 0.0 & 0.0 & 0.0 & 0.0 & 0.0 & 0.0 & 0.0 & 0.0 & $\mathrm{n} / \mathrm{a}$ \\
\hline flowering dogwood & 0.0 & 0.0 & 0.0 & 0.0 & 0.5 & 0.1 & 0.0 & 0.0 & 0.0 & 0.0 & 0.0 & 0.0 & 0.0 & 0.0 & $\mathrm{n} / \mathrm{a}$ \\
\hline ironwood & 0.0 & 0.0 & 0.0 & 0.0 & 0.3 & 0.6 & 0.0 & 0.0 & 0.0 & 0.0 & 0.0 & 0.0 & 0.0 & 0.0 & $\mathrm{n} / \mathrm{a}$ \\
\hline northern red oak & 0.0 & 0.0 & 0.0 & 0.0 & 0.0 & 0.0 & 0.0 & 0.0 & 0.0 & 0.0 & 0.1 & 0.0 & 0.0 & 0.0 & $\mathrm{n} / \mathrm{a}$ \\
\hline alternate-leaf dogwood & 0.0 & 0.0 & 0.0 & 0.0 & 0.0 & 0.0 & 0.0 & 0.0 & 0.0 & 0.0 & 0.0 & 0.0 & 0.0 & 0.0 & $\mathrm{n} / \mathrm{a}$ \\
\hline chestnut oak & 0.0 & 0.0 & 0.0 & 0.0 & 0.0 & 0.0 & 0.0 & 0.0 & 0.0 & 0.0 & 0.0 & 0.0 & 0.0 & 0.0 & $\mathrm{n} / \mathrm{a}$ \\
\hline sassafras & 0.0 & 0.0 & 0.0 & 0.0 & 0.0 & 0.0 & 0.0 & 0.0 & 0.0 & 0.0 & 0.0 & 0.0 & 0.0 & 0.4 & $\mathrm{n} / \mathrm{a}$ \\
\hline white oak & 0.0 & 0.0 & 0.0 & 0.0 & 0.0 & 0.0 & 0.0 & 0.0 & 0.0 & 0.0 & 0.0 & 0.0 & 0.0 & 0.3 & $\mathrm{n} / \mathrm{a}$ \\
\hline
\end{tabular}

${ }^{\mathrm{a}} \mathrm{D}=$ dominant crown class; $\mathrm{CD}=\mathrm{co-dominant}$ crown class; I = intermediate crown class; OT = overtopped crown class

${ }^{\mathrm{b}} \mathrm{OS}=$ total overstory (all crown classes); US = understory

${ }^{\mathrm{c}}$ Preharvest data not available 
Table 8: Relative Trees per Hectare for each Age Class, Crown Class ${ }^{a}$, and Canopy Strata ${ }^{b}$

\begin{tabular}{|c|c|c|c|c|c|c|c|c|c|c|c|c|c|c|c|c|c|}
\hline \multirow[b]{2}{*}{ Species } & \multicolumn{3}{|c|}{ 2-6 Years } & \multicolumn{6}{|c|}{ 12-16 Years } & \multicolumn{6}{|c|}{ 22-26 Years } & \multicolumn{2}{|c|}{ Pre-Harvest } \\
\hline & $<.31 \mathrm{~m}$ & $\geq .31 \mathrm{~m}-<1.37 \mathrm{~m}$ & $\geq 1.37 \mathrm{~m}$ & $\mathrm{D}$ & $C D$ & 1 & OT & OS & US & $\mathrm{D}$ & CD & 1 & OT & OS & US & os & US \\
\hline yellow poplar & 30.7 & 17.2 & 15.8 & 25.2 & 26.8 & 23.9 & 16.9 & 22.2 & 0.0 & 43.0 & 50.1 & 30.5 & 17.9 & 32.9 & 10.5 & 17.8 & 2.0 \\
\hline sugar maple & 35.1 & 20.9 & 17.7 & 0.0 & 11.0 & 19.6 & 27.6 & 18.8 & 47.6 & 0.0 & 2.1 & 9.5 & 45.1 & 22.5 & 44.8 & 18.9 & 58.8 \\
\hline black locust & 0.2 & 0.7 & 1.7 & 59.4 & 10.8 & 2.9 & 2.1 & 8.1 & 0.0 & 47.4 & 2.0 & 0.0 & 0.0 & 1.1 & 0.0 & 3.7 & 1.2 \\
\hline American basswood & 2.3 & 0.5 & 0.4 & 2.5 & 12.0 & 4.6 & 6.2 & 7.7 & 15.9 & 0.0 & 8.8 & 20.1 & 14.9 & 13.0 & 4.3 & 16.8 & 3.9 \\
\hline black birch & 9.1 & 25.5 & 40.3 & 3.4 & 11.1 & 13.3 & 6.9 & 9.5 & 0.0 & 0.0 & 6.5 & 14.1 & 3.5 & 6.2 & 0.0 & 2.5 & 1.9 \\
\hline red elm & 0.0 & 0.0 & 0.8 & 0.0 & 7.5 & 7.7 & 6.6 & 6.8 & 28.6 & 0.0 & 3.9 & 5.1 & 0.1 & 2.3 & 8.2 & 4.1 & 0.0 \\
\hline black cherry & 2.8 & 4.0 & 1.1 & 0.0 & 0.5 & 0.0 & 0.0 & 0.2 & 0.0 & 9.6 & 13.4 & 5.6 & 9.7 & 10.7 & 7.2 & 2.9 & 0.5 \\
\hline American beech & 4.0 & 5.9 & 1.9 & 0.0 & 4.2 & 7.5 & 11.0 & 7.4 & 7.9 & 0.0 & 0.0 & 0.0 & 0.2 & 0.1 & 10.0 & 8.9 & 19.2 \\
\hline striped maple & 1.2 & 3.1 & 8.3 & 0.0 & 2.3 & 5.8 & 8.1 & 5.2 & 0.0 & 0.0 & 1.8 & 1.5 & 1.8 & 1.8 & 0.0 & 0.0 & 1.2 \\
\hline devils-walkingstick & 0.7 & 3.1 & 4.0 & 3.4 & 6.5 & 9.8 & 5.8 & 6.7 & 0.0 & 0.0 & 0.0 & 0.0 & 0.0 & 0.0 & 0.0 & 0.0 & 0.0 \\
\hline white ash & 2.1 & 4.3 & 1.4 & 0.0 & 3.8 & 5.0 & 5.6 & 4.6 & 0.0 & 0.0 & 5.3 & 6.0 & 2.3 & 4.0 & 1.6 & 3.4 & 1.4 \\
\hline yellow birch & 0.0 & 0.0 & 0.0 & 0.0 & 0.5 & 0.0 & 1.4 & 0.7 & 0.0 & 0.0 & 0.3 & 3.1 & 0.0 & 0.5 & 10.3 & 2.0 & 0.4 \\
\hline hickory & 0.2 & 1.0 & 0.0 & 0.0 & 0.5 & 0.0 & 0.7 & 0.3 & 0.0 & 0.0 & 3.9 & 2.2 & 3.5 & 0.7 & 1.1 & 0.0 & 0.4 \\
\hline fire cherry & 0.1 & 0.0 & 0.7 & 5.1 & 0.2 & 0.0 & 0.0 & 0.5 & 0.0 & 0.0 & 1.6 & 0.0 & 0.0 & 3.4 & 0.8 & 6.9 & 0.0 \\
\hline northern red oak & 4.0 & 8.4 & 3.9 & 0.0 & 0.0 & 0.0 & 0.0 & 0.0 & 0.0 & 0.0 & 0.0 & 0.0 & 0.7 & 0.3 & 0.0 & 7.2 & 0.3 \\
\hline red maple & 5.7 & 2.3 & 0.4 & 0.0 & 0.7 & 0.0 & 0.0 & 0.5 & 0.0 & 0.0 & 0.0 & 0.0 & 0.0 & 0.2 & 0.0 & 3.0 & 3.8 \\
\hline cucumber magnolia & 0.8 & 1.2 & 0.5 & 1.0 & 1.2 & 0.0 & 0.0 & 0.0 & 0.0 & 0.0 & 0.3 & 0.0 & 0.2 & 0.3 & 0.0 & 0.1 & 0.3 \\
\hline butternut & 0.0 & 0.0 & 0.0 & 0.0 & 0.0 & 0.0 & 0.0 & 0.2 & 0.0 & 0.0 & 0.0 & 2.3 & 0.0 & 0.0 & 0.0 & 0.9 & 0.0 \\
\hline American hornbeam & 0.0 & 0.0 & 0.0 & 0.0 & 0.0 & 0.0 & 0.0 & 0.0 & 0.0 & 0.0 & 0.0 & 0.0 & 0.0 & 0.0 & 1.1 & 0.0 & 0.0 \\
\hline flowering dogwood & 0.3 & 0.5 & 0.0 & 0.0 & 0.0 & 0.0 & 0.7 & 0.3 & 0.0 & 0.0 & 0.0 & 0.0 & 0.0 & 0.0 & 0.0 & 0.0 & 0.0 \\
\hline sassafras & 0.7 & 1.0 & 0.8 & 0.0 & 0.0 & 0.0 & 0.0 & 0.2 & 0.0 & 0.0 & 0.0 & 0.0 & 0.0 & 0.0 & 0.0 & 0.0 & 0.0 \\
\hline staghorn sumac & 0.0 & 0.0 & 0.0 & 0.0 & 0.5 & 0.0 & 0.0 & 0.0 & 0.0 & 0.0 & 0.0 & 0.0 & 0.0 & 0.0 & 0.0 & 0.0 & 0.0 \\
\hline ironwood & 0.0 & 0.1 & 0.0 & 0.0 & 0.0 & 0.0 & 0.3 & 0.1 & 0.0 & 0.0 & 0.0 & 0.0 & 0.0 & 0.0 & 0.0 & 0.1 & 2.7 \\
\hline alternate-leaf dogwood & 0.0 & 0.1 & 0.2 & 0.0 & 0.0 & 0.0 & 0.0 & 0.0 & 0.0 & 0.0 & 0.0 & 0.0 & 0.0 & 0.0 & 0.0 & 0.0 & 0.0 \\
\hline chestnut oak & 0.0 & 0.1 & 0.0 & 0.0 & 0.0 & 0.0 & 0.0 & 0.0 & 0.0 & 0.0 & 0.0 & 0.0 & 0.0 & 0.0 & 0.0 & 0.6 & 0.3 \\
\hline white oak & 0.1 & 0.0 & 0.0 & 0.0 & 0.0 & 0.0 & 0.0 & 0.0 & 0.0 & 0.0 & 0.0 & 0.0 & 0.0 & 0.0 & 0.0 & 0.1 & 0.0 \\
\hline
\end{tabular}

${ }^{\mathrm{a}} \mathrm{D}=$ dominant crown class; $\mathrm{CD}=$ co-dominant crown class; I = intermediate crown class; OT = overtopped crown class

${ }^{\mathrm{b}} \mathrm{OS}=$ total overstory (all crown classes); US = understory 
Table 9: Trees with Sprout Origin in Postharvest Stands

\begin{tabular}{|lrr|}
\hline species & $\begin{array}{c}\text { All Trees } \\
\text { all stands } \\
\text { (\% trees/ha) }\end{array}$ & $\begin{array}{c}\text { Overstory } \\
\text { stands } \geq 12 \text { yrs. } \\
\text { (\% trees/ha) }\end{array}$ \\
\hline American basswood & 88 & 89 \\
red elm & 60 & 56 \\
American beech & 47 & 74 \\
sugar maple & 39 & 44 \\
striped maple & 34 & 33 \\
white ash & 18 & 18 \\
black birch & 11 & 13 \\
red maple & 11 & 100 \\
cucumber magnolia & 10 & 25 \\
yellow poplar & 10 & 20 \\
black locust & 9 & 3 \\
yellow birch & 5 & 22 \\
northern red oak & 3 & 0 \\
black cherry & 2 & 8 \\
\hline
\end{tabular}


Figure 1: Inventory Plot Layout

Plot Layout without 0.02 ha plots

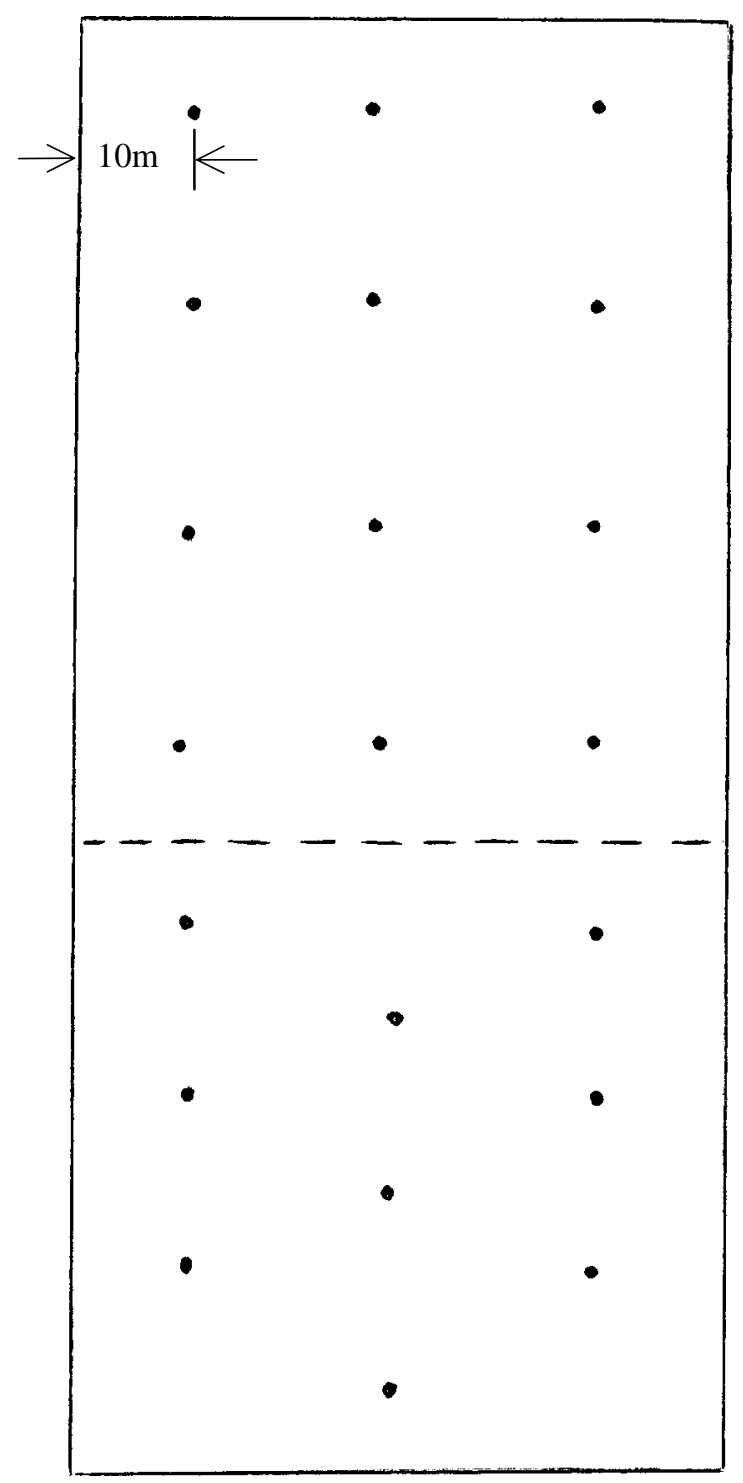

Plot Layout with 0.02 ha plots 


\section{Figure 2: DCA: Pre and Postharvest Importance Value Ordination}
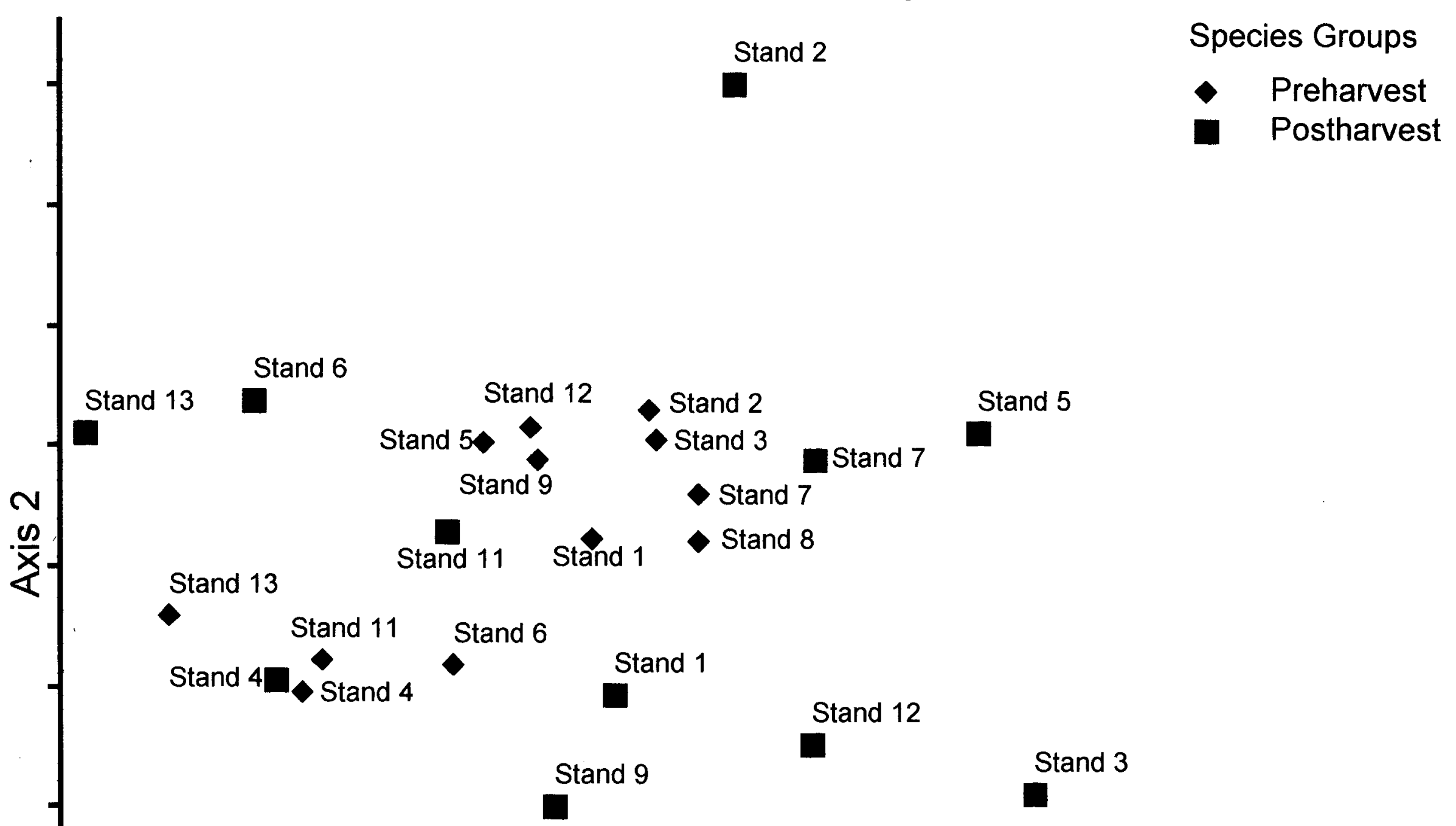

Stand 9

Stand 12

$\square$

Stand 8

- 


\section{Figure 3: DCA: Postharvest Importance Value Ordination}

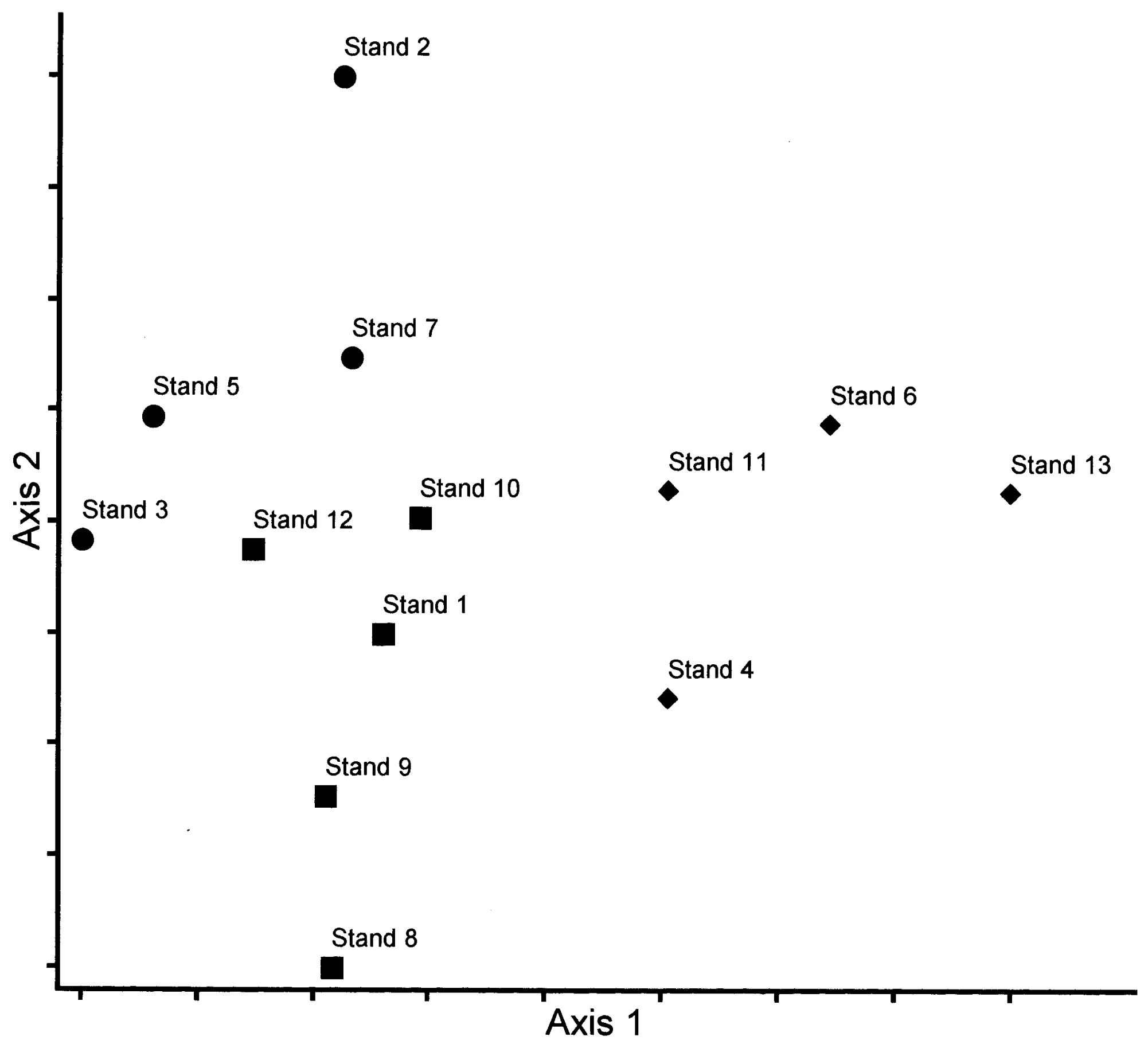

Species Groups

- High Yellow-Poplar

- High Sugar Maple

- High Black Birch

Stand 6

Stand 4 
Figure 4: Overstory Composition

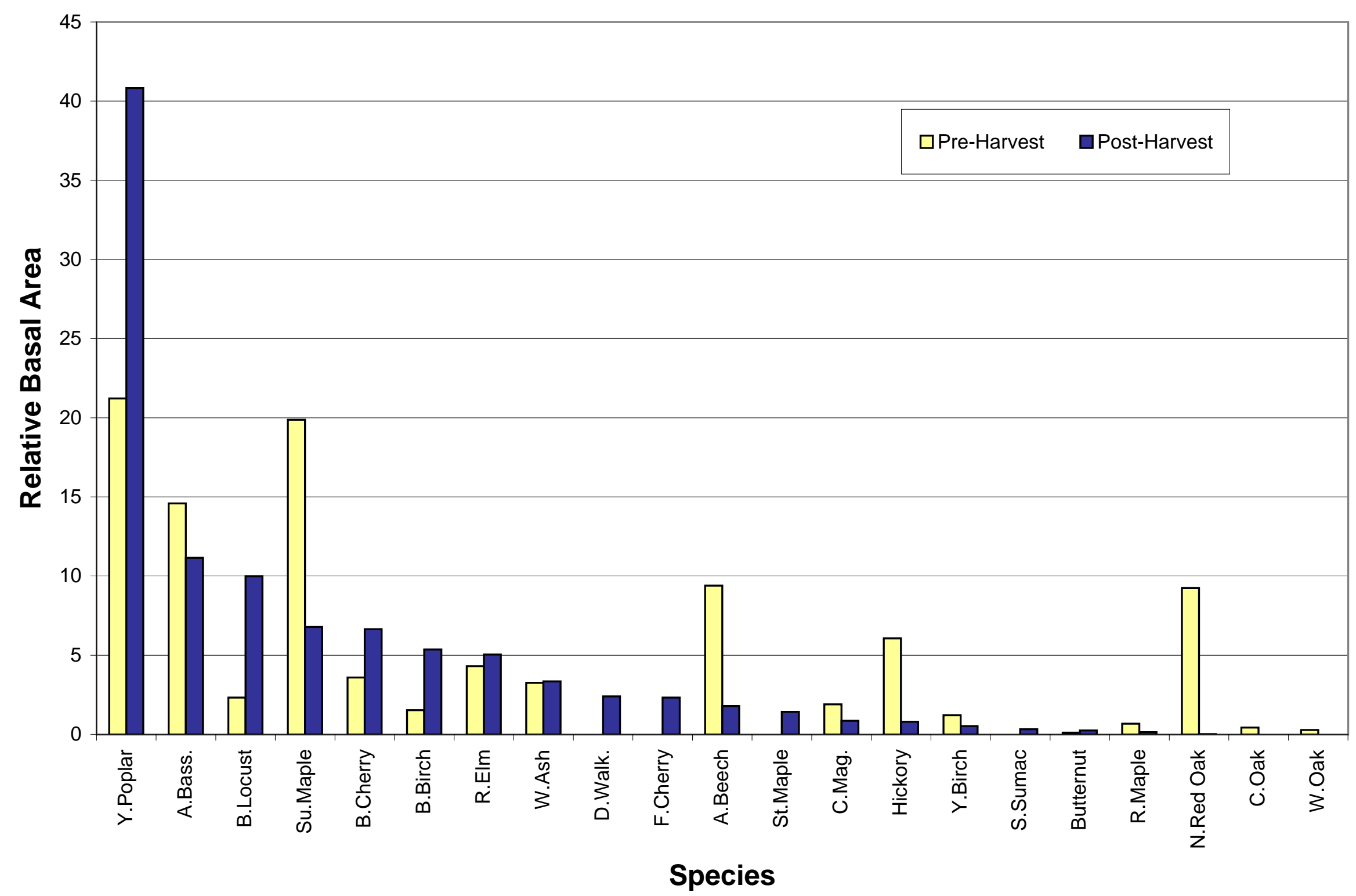


Figure A1: Study Area 1

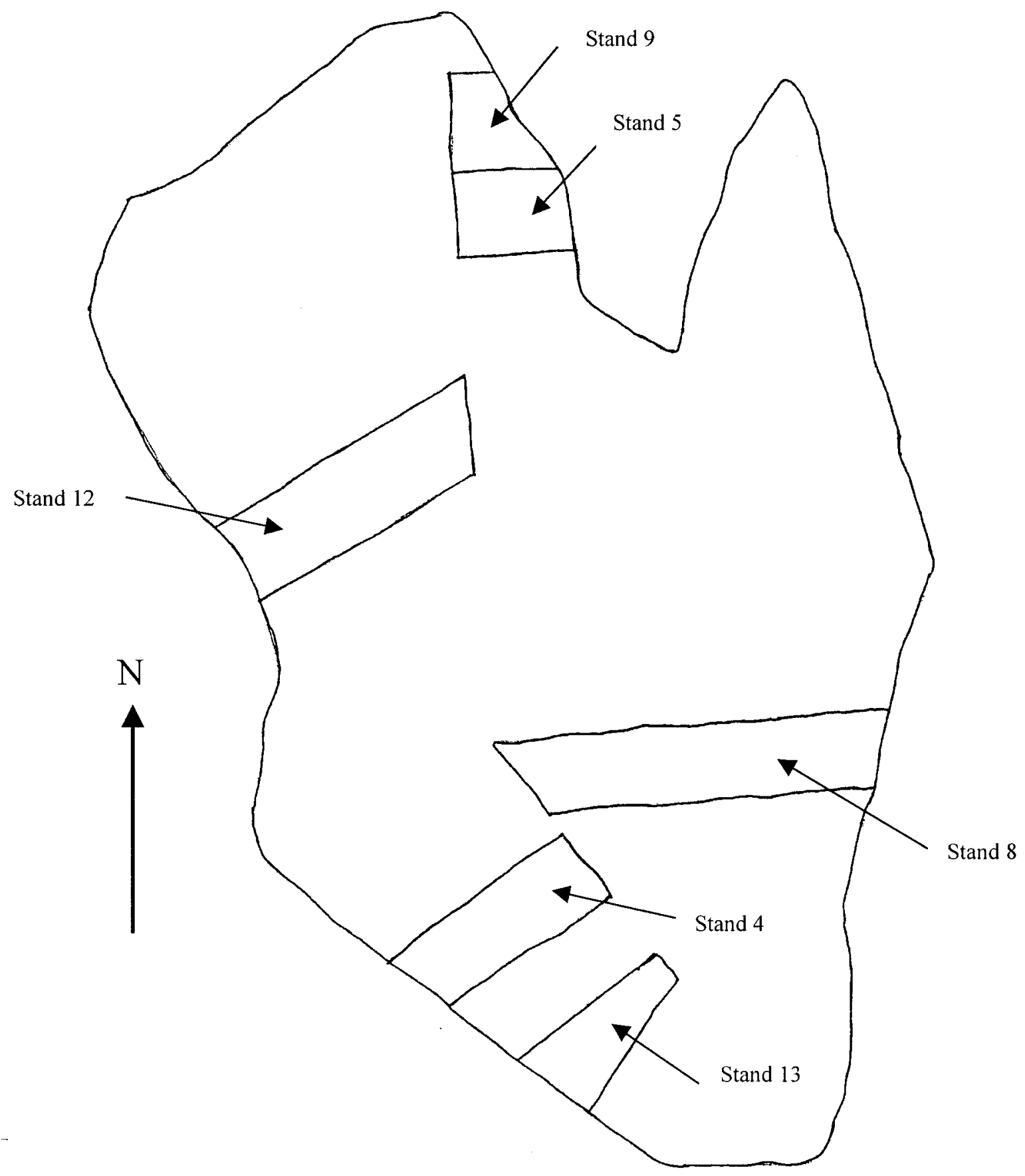


Figure A2: Study Area 2

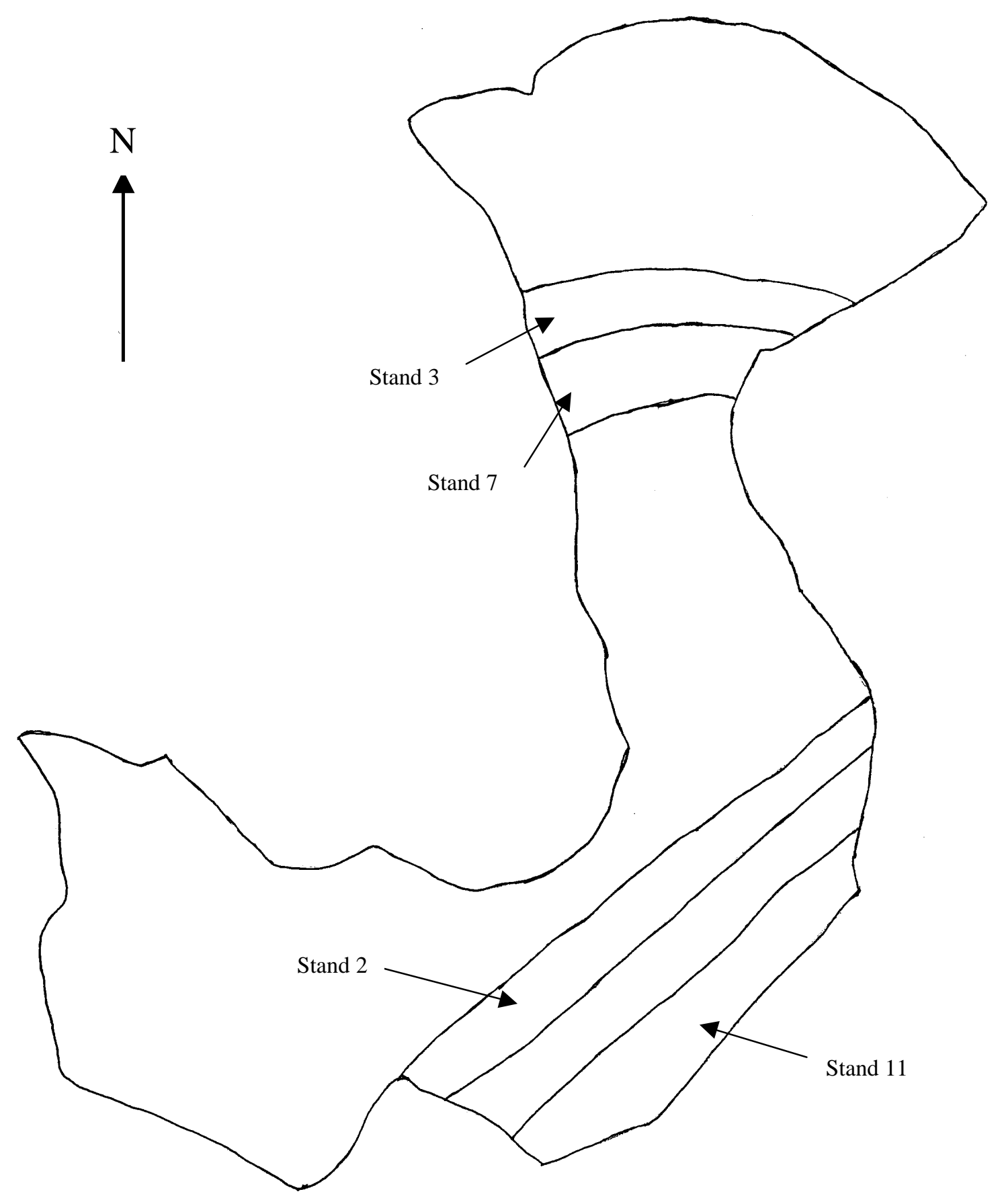


Figure A3: Study Area 3

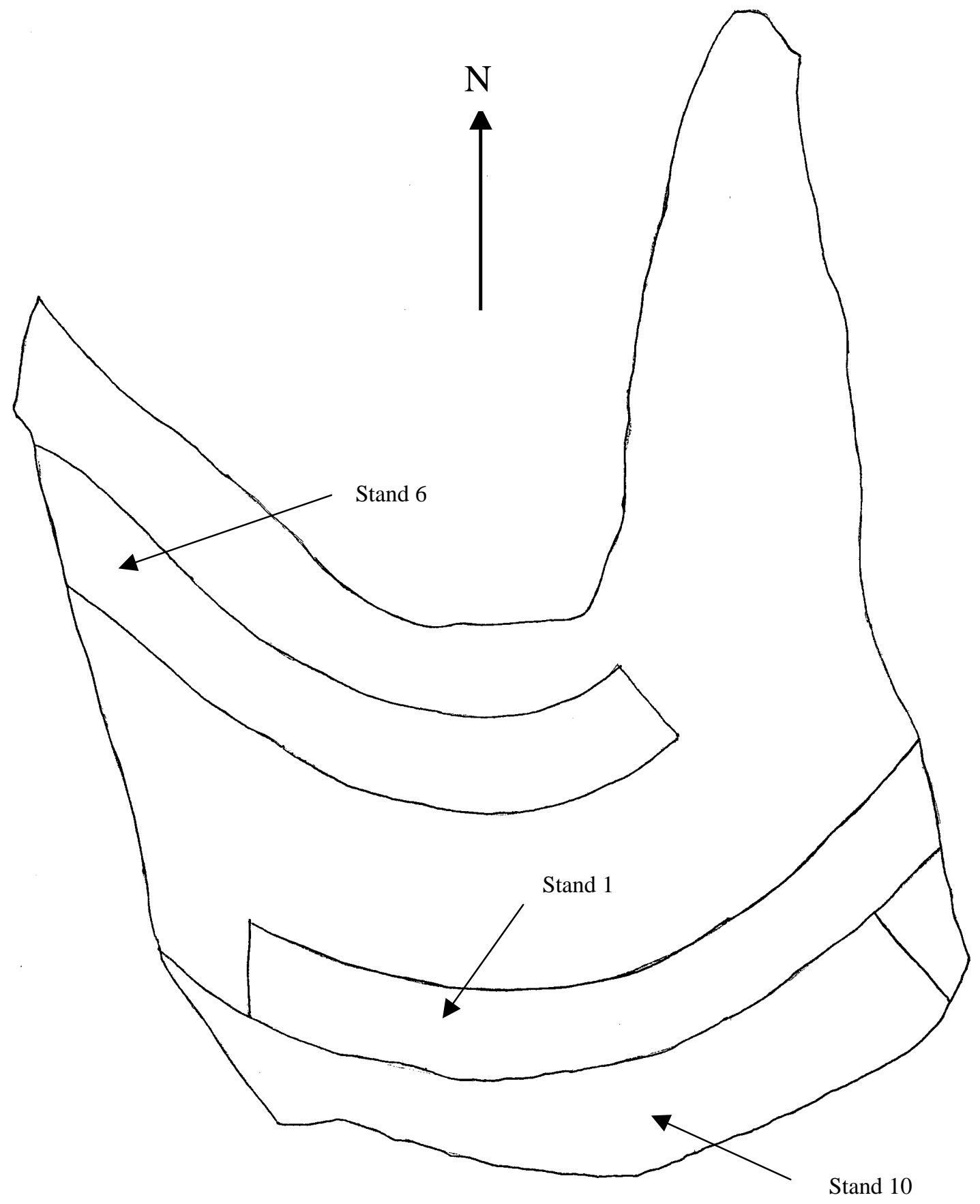

